\title{
Evaluation of surface properties and atmospheric disturbances caused by post-dam alterations of land use/land cover
}

\author{
A. T. Woldemichael ${ }^{1}$, F. Hossain ${ }^{2}$, and R. Pielke Sr. ${ }^{3}$ \\ ${ }^{1}$ Department of Civil and Environmental Engineering, Tennessee Technological University, Cookeville, Tennessee, USA \\ ${ }^{2}$ Department of Civil and Environmental Engineering, University of Washington, Washington, USA \\ ${ }^{3}$ Cooperative Institute for Research in Environmental Sciences (CIRES), University of Colorado, Boulder, Colorado, USA
}

Correspondence to: A. T. Woldemichael (abel_tad2000@yahoo.com)

Received: 1 April 2014 - Published in Hydrol. Earth Syst. Sci. Discuss.: 16 May 2014

Revised: 27 August 2014 - Accepted: 27 August 2014 - Published: 26 September 2014

\begin{abstract}
This study adopted a differential land-use/landcover (LULC) analysis to evaluate dam-triggered landatmosphere interactions for a number of LULC scenarios. Two specific questions were addressed: (1) can damtriggered LULC heterogeneities modify surface and energy budget, which, in turn, change regional convergence and precipitation patterns? (2) How extensive is the modification in surface moisture and energy budget altered by damtriggered LULC changes occurring in different climate and terrain features? The Regional Atmospheric Modeling System (RAMS, version 6.0) was set up for two climatologically and topographically contrasting regions: the American River watershed (ARW), located in California, and the Owyhee River watershed (ORW), located in eastern Oregon. For the selected atmospheric river precipitation event of 29 December 1996 to 3 January 1997, simulations of three pre-defined LULC scenarios are performed. The definition of the scenarios are (1) the "control" scenario, representing the contemporary land use, (2) the "pre-dam" scenario, representing the natural landscape before the construction of the dams and (3) the "non-irrigation" scenario, representing the condition where previously irrigated landscape in the control is transformed to the nearby land-use type. Results indicated that the ARW energy and moisture fluxes were more extensively affected by dam-induced changes in LULC than the ORW. Both regions, however, displayed commonalities in the modification of land-atmosphere processes due to LULC changes, with the control-non-irrigation scenario creating more change than the control-pre-dam scenarios. These commonalities were: (1) the combination of a decrease in temperature (up to $0.15^{\circ} \mathrm{C}$ ) and an increase
\end{abstract}

at dew point (up to $0.25^{\circ} \mathrm{C}$ ) was observed; (2) there was a larger fraction of energy partitioned to latent heat flux (up to $10 \mathrm{~W} \mathrm{~m}^{-2}$ ) that increased the amount of water vapor in the atmosphere and resulted in a larger convective available potential energy (CAPE); (3) low-level wind-flow variation was found to be responsible for pressure gradients that affected localized circulations, moisture advection and convergence. At some locations, an increase in wind speed up to $1.6 \mathrm{~m} \mathrm{~s}^{-1}$ maximum was observed; (4) there were also areas of well-developed vertical motions responsible for moisture transport from the surface to higher altitudes that enhanced precipitation patterns in the study regions.

\section{Introduction}

LULC modifications, in the post-dam era, often lead to changes in land-surface (soil properties) and vegetation characteristics, such as albedo, root distribution and roughness height (Narisma and Pitman, 2003). For instance, Narisma and Pitman (2003) pointed out that conversion of a tree into grass reduces leaf area index (LAI), increases albedo and decreases roughness length. Zhao and Pitman (2002) found out that the change in vegetation cover from forest to grass and crops causes a large reduction in roughness height, resulting in an increase in low-level wind fields. From a hydrometeorological point of view, such transformations affect the available water-flow regime that influences soil moisture and precipitation. These changes also regulate the partitioning of energy between sensible and latent heat, boundary layer structures, local air temperature and wind patterns (Betts et 
al., 1996; Sud and Smith, 1985; Zhang et al., 1996; Zhao and Pitman, 2002).

Irrigation practices, which are one of the major post-dam LULC changes, for instance, can modify not only the precipitation pattern but also the surface moisture and energy distribution, which alter boundary layers and regional convergence, as well as mesoscale convection (Douglas et al., 2009). Irrigation also has an effect of cooling the ambient surface and near-surface temperature by decreasing the sensible heat fluxes and increasing latent heat fluxes (Boucher et al., 2004; Eungul et al., 2011), thus increasing the convective available potential energy (CAPE) (Pielke Sr., 2001). The added moist enthalpy from irrigation tends to create strong spatial gradients of CAPE with respect to the surrounding non-irrigated landscape, which, in turn, can produce localized wind circulations. This process can enhance the likelihood of convective precipitation.

Another component of the post-dam induced LULC modification can be downstream urbanization. In urban landscapes, surface properties are drastically modified, resulting in a modification of the energy budget and precipitation distribution (Shepherd, 2005). There is also an increase in surface roughness as compared to a previously uninhabited area. This increase in surface roughness creates a slower nearsurface wind that facilitates convergence and assists in convective cell formation. Surface albedo is also modified as a result of the altered surface conditions due to urbanization.

It is plausible that the future points to a continuing trend for construction of more dams to satisfy societal demands for water- and flood-disaster alleviation, particularly in the developing world (Graf, 1999). As a result, LULC changes will also accelerate in the 21st century (Pitman, 2003). The pressing issue, however, is how to create a scientifically credible link among the LULC changes that occur after the construction of a dam, the associated alteration in the land-surface properties and their interaction with atmospheric conditions.

The underlying objective of why the need arises to assess anthropogenic-land-atmosphere interactions should be perceived from the effect that such assessments have on the formation and modification of precipitation. According to Georgescu (2008), the positive feedback created by the complex land-atmosphere interactions within the planetary boundary layer (PBL) establish a physical pathway for the enhancement of precipitation. Precipitation by itself can serve as a feedback mechanism (through the soilprecipitation feedback) by allowing for more soil-moisture storage and further moisture supply through physical evaporation and transpiration, and precipitation recycling (Schar et al., 1998). Betts et al. (1996) also suggested that there is a positive feedback between soil moisture, surface evaporation and precipitation. This loop of complex interrelationship warrants the evaluation of all aspects of processes involved within the PBL in addition to precipitation.
In recent years, the scientific community has given attention to the impacts induced by LULC changes (such as irrigation and urbanization) on weather and climate. However, only a few quantitative and numerical-modeling assessments address the effects of the combined changes that are apparent due to the presence of dams (Hossain et al., 2012; Degu and Hossain, 2012; DeAngelis et al., 2010; Woldemichael et al., 2012, 2013) and contrasting settings. There remains a large gap in understanding the post-dam feedback due to LULC variability on surface properties and atmospheric disturbances.

Numerical-modeling approaches, in a wide range of LULC scenarios, have been used to evaluate localized atmospheric disturbances. For instance, the Regional Atmospheric Modeling System (RAMS) was applied for the assessment of interactions between atmospheric processes, such as mesoscale circulations and cloud formations, and land-surface processes, such as heat and moisture fluxes from a set of different LULC scenarios (Stohlgren et al., 1998). The model was also implemented to evaluate the influence of anthropogenic landscape changes on the atmospheric conditions in South Florida (Pielke Sr. et al., 1999). The hydrometeorological effects of land-use heterogeneities on various spatial and temporal scales have also been modeled using different types of atmospheric models (Narisma and Pitman, 2006; Schneider et al., 2004; Marshall et al., 2010; Douglas et al., 2006; ter Maat et al., 2013).

This study focuses on the evaluation of human-landatmosphere interactions through a differential LULC-change analysis, for a number of pre-defined LULC scenarios using the RAMS. The study tries to address the associated atmospheric disturbances due to variations in LULC properties that occur after dam construction for regions of different climatic zones. Moreover, the following two specific questions were addressed: (1) can LULC heterogeneities that result due to the presence of a dam modify surface and energy budget which, in turn, change regional convergence and precipitation patterns? (2) How extensive is the modification in surface moisture and energy budget altered by LULC changes near artificial reservoirs occurring in different climate and terrain features?

Previous works, reported in Woldemichael et al. (2012, 2013), investigated effects of land-use heterogeneities on modification of extreme precipitation for the same regions. Those studies reported that there was discernible alteration of extreme precipitation that resulted from the dam-induced changes in LULC. Findings of the present study allow for comparisons of the role of the localized mesoscale circulations against the changes observed in the extreme precipitation patterns. The previous two works focused entirely on a numerical-modeling approach to estimate extreme precipitation (EP), and discussions about how the engineering community can benefit from such approaches in a changingclimate situation. In this paper, particular emphasis is placed on the actual storm patterns, which has very little to do with 
extremes. It addresses the behavior of storm dynamics and how this behavior is affected in a changing LULC situation.

As a broader impact, such findings can assist engineers and managers to establish weather and climate monitoring protocols, in addition to existing observation platforms in regions where dam-induced LULC changes are prominent. The paper is organized as follows: Sect. 2 presents the study region; Sect. 3 explains the data and methods used in the study; Sect. 4 discusses the results; finally, Sect. 5 presents the conclusions and recommendations of the study.

\section{Study regions}

Based on climatological and topographical contrasts, the Folsom Dam and Reservoir on the American River, windward of the Sierra-Nevada, and the Owyhee Dam and Reservoir on the Owyhee River, leeward of the Cascades, were selected for this study. The Folsom Dam is located about 20 miles northeast of the city of Sacramento, California (Ferrari, 2005). The reservoir impounds the American River above Folsom Dam that covers a watershed area of $4823 \mathrm{~km}^{2}$ (USACE, 2005). The major purposes of the reservoir include irrigation, water supply, power generation, flood control and recreation. The climate of the American River watershed (ARW) is predominantly continental and receives rain primarily during the winter season (http://www.eoearth.org/article/).

The Owyhee Dam, on the other hand, is located in Malheur County, Oregon, and its reservoir impounds a watershed area of $26617 \mathrm{~km}^{2}$ (USBR, 2009). The major purpose of the reservoir is to irrigate the arid deserts occupied by the Owyhee irrigation district. Other purposes also include flood damage reduction, fishery, recreation and hydropower. The Owyhee River watershed (ORW) predominantly belongs to dry (arid) climate that receives little or no precipitation during most of the year.

The Folsom Dam and the Owyhee Dam became functional in 1955 and 1932, respectively. During the post-dam era, the natural landscape altered significantly in both regions where land was converted to irrigated agriculture and downstream regions became more urbanized. Figure 1 shows the contemporary LULC of both ARW and ORW, along with the simulation domains as of 2003. The post-dam era had also experienced extreme flood events that resulted in unprecedented damage in life and property. For instance, both regions were highly affected by the 1996-1997 flood (the so-called "newyear's eve flood"), where very heavy precipitation generated a devastating runoff that triggered a relook of management and operation of the dams.

The common underlying hydrometeorological factor that contributed to the 1996-1997 flooding episode was the presence of "atmospheric rivers" (ARs), which accounted for advective transport of water vapor along highly concentrated streamlines (Dettinger et al., 2012). The ARs that extended over much of California and the Pacific Northwest, when assisted with a strong low-level wind, carried a large amount of moisture from the Pacific Ocean that eventually precipitated inland. In this study, we put forward the premise that dam-induced LULC changes during the postdam era may have further influenced the storm through human-land-atmosphere feedback mechanisms. We hypothesize that these LULC changes played a role in modifying the surface properties and atmospheric circulations creating a pathway for precipitation intensification for the 19961997 event. Accordingly, this study selected the 1996-1997 heavy precipitation episode. Moreover, the 1996-1997 flood episode is consistent with the flood period studied in previous separate works of extreme precipitation modification on ARW and ORW (Woldemichael et al., 2012, 2013). Consistency in the study periods allowed us to explore a relationship among the observed extreme precipitation and the forcings and feedback for the precipitation formation. Moreover, the winters in these regions are favorable seasons for crops that cannot take the summer heat and hence the anticipated LULC change is also there in the winter time.

\section{Data and methods}

\subsection{Land-use/land-cover (LULC) scenarios}

Figure 1 shows the existing state of the LULC in the respective study regions, as per the MODIS (Moderateresolution Imaging Spectroradiometer) land-cover-type product (MCD12Q1, https://lpdaac.usgs.gov/). The MODISLULC, with a footprint of $500 \mathrm{~m} \times 500 \mathrm{~m}$, uses a supervised classification algorithm that is estimated by utilizing a database of high-quality land-cover training sites, developed using high-resolution imagery (Muchoney et al., 1999).

In the first LULC scenario, the control (as shown in Fig. 1, top panel), represents the contemporary landscape of the study regions. In order to separate out the influence of the irrigated agriculture on land-atmosphere interaction, the second scenario represented the non-irrigation. Finally, the third scenario (pre-dam) assimilated the no-dam/reservoir condition with the natural (undisturbed) landscape. These LULC scenarios are established based on the hypothesis that most anthropogenic changes around dams are prominent right after the dam becomes functional (i.e., the post-dam was represented by the control scenario in this case).

In order to represent the non-irrigation scenario, irrigation extent was initially extracted from the global maps of irrigated areas from the Oak Ridge National Laboratory Distributed Active Archive Center (ORNL DAAC) for Biogeochemical Dynamics data source (also found at http://webmap.ornl.gov/). The initial extractions are shown in Figs. 2a and c both for ORW and ARW, respectively. The grid-cell units are provided as percentage coverage and, in this study, regions with $50 \%$ or more irrigation coverage in each grid cell are predominantly assumed to be irrigated. 

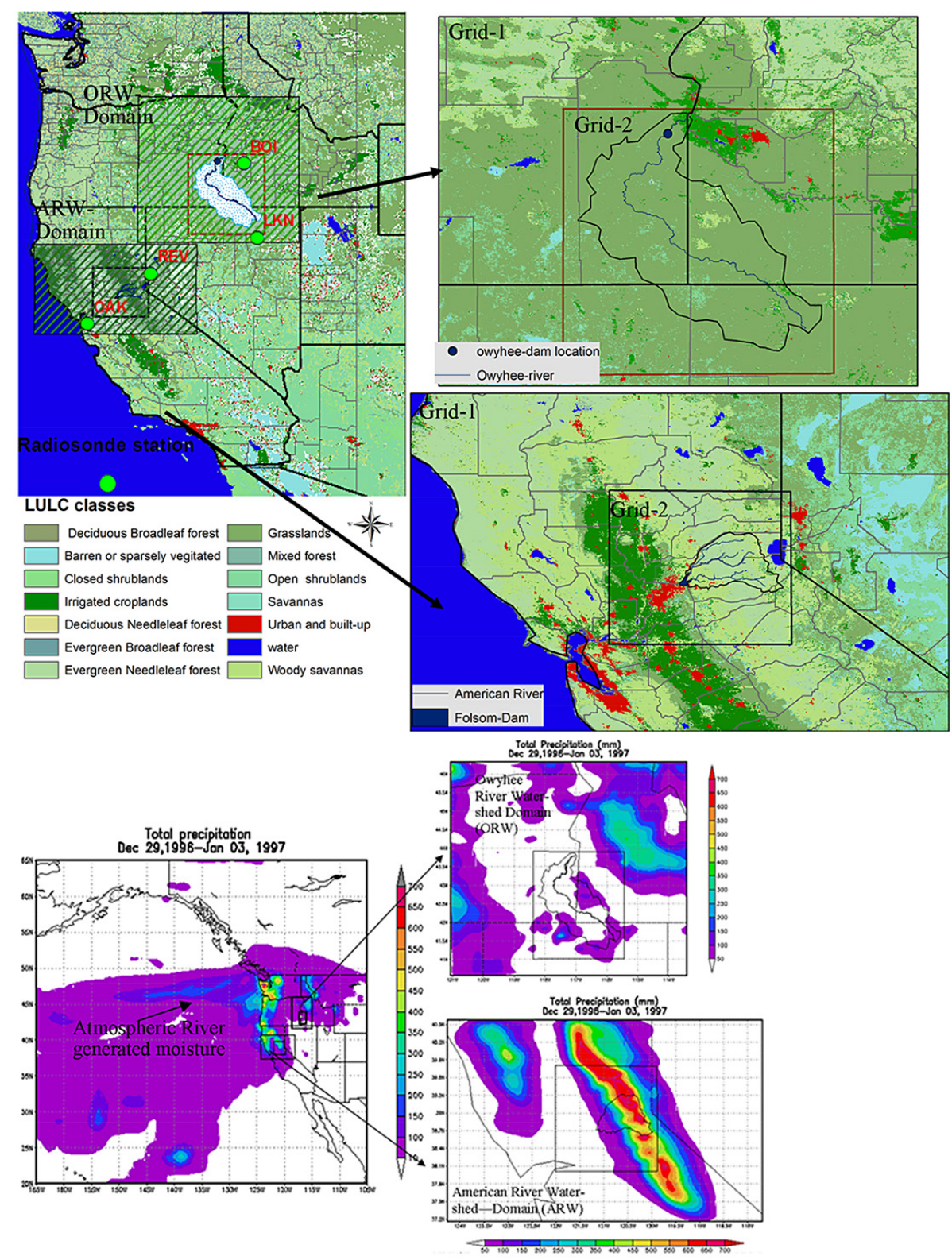

Figure 1. The contemporary LULC (i.e., control scenario) of the study regions, along with simulation domains for both ARW and ORW (top panel). Courtesy of MODIS land-cover-type product or MCD12Q1 (also available at http://glcf.umiacs.umd.edu/). Lower panel represents 6-day total precipitation (maximum of $350 \mathrm{~mm}$ for ORW and $700 \mathrm{~mm}$ for ARW) that was result of the same atmospheric river (AR) event.

This kind of approach has also been previously adopted in the works of Douglas et al. (2009), where they assumed a threshold of $50 \%$ or more as irrigated cropland. Accordingly, the irrigated patch was generated with this assumption and is shown as an overlay map (Figs. $2 b$ and $d$ ). To represent the non-irrigation scenario, this land coverage is converted to the nearby land-cover type (woody savanna in the case of ARW and grassland in case of ORW). The urban area is also hypothetically assumed to be converted accordingly.

In order to represent the pre-dam scenario, there were a set of steps followed in the process of recreating the $1950 \mathrm{~s}$
LULC for ARW and the 1930s LULC for ORW, respectively. The transformations were made in closer proximity to the respective watersheds. First, the pre-dam land use for both regions was extracted from the History Database of the Global Environment (HYDE) website (also available at: http://themasites.pbl.nl/tridion/en/themasites/hyde/ download/index-2.html). HYDE was developed under the authority of the Netherlands Environmental Assessment Agency and presents gridded time series of population and land use for the last 12000 years. According to HYDE, land use was allocated as cropland and grassland under six 


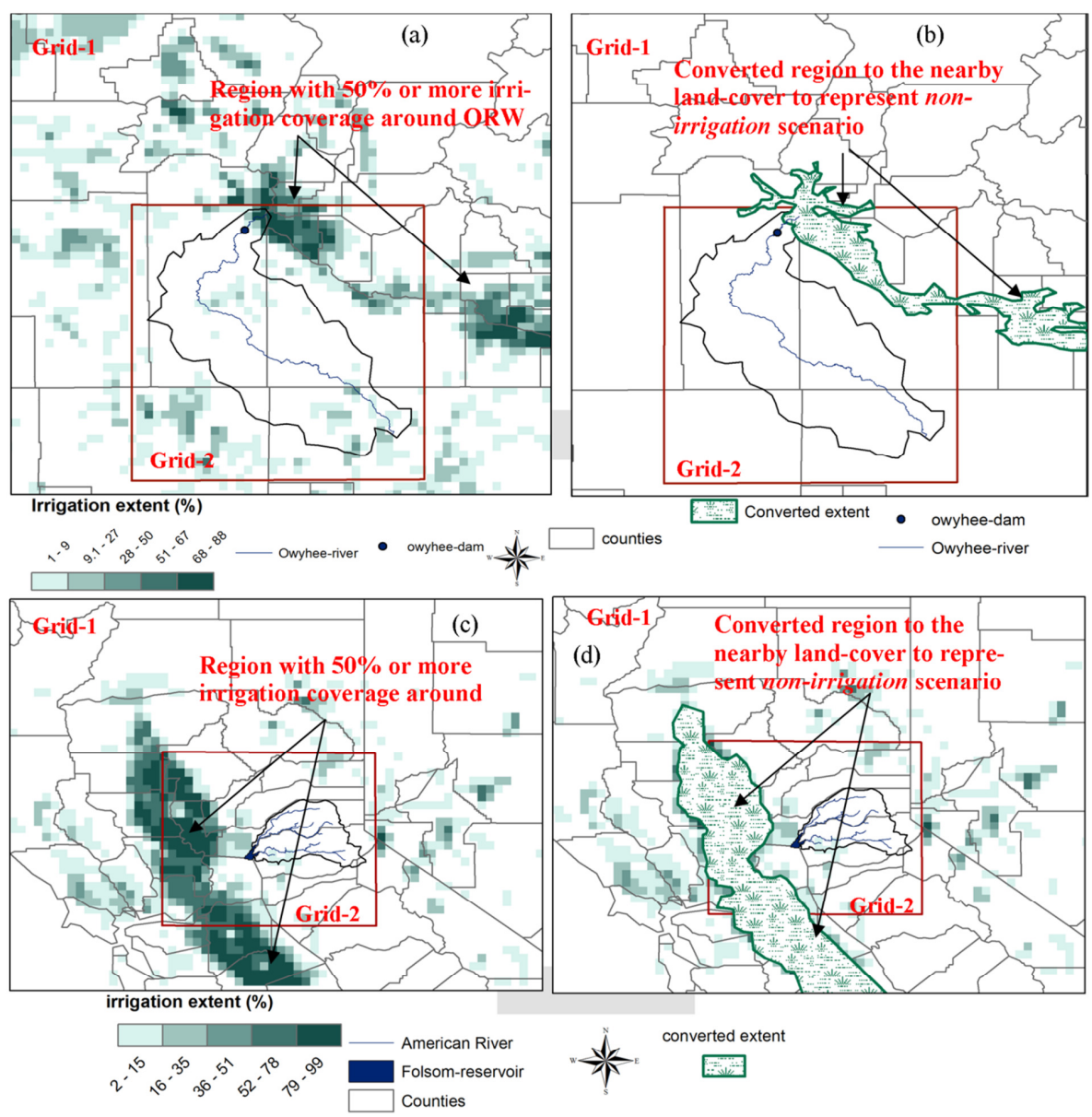

Figure 2. Generated irrigated land cover to establish the non-irrigation scenarios. Irrigation extent initially extracted from the global maps of irrigated areas from the Oak Ridge National Laboratory Distributed Active Archive Center (ORNL DAAC) for Biogeochemical Dynamics data source (also found at http://webmap.ornl.gov/).

assumptions mentioned on the HYDE site, and, in this study, the 1950s land use for ARW and the 1930s land use for ORW were extracted. The percentage coverage of each crop and grass is spatially represented in Figs. $3 \mathrm{a}$ and $\mathrm{c}$ for ORW and Figs. $4 \mathrm{a}$ and $\mathrm{c}$ for ARW. The analysis was made with the aid of the geographic information system (GIS).

Second, the representation of the cropland and grassland was made by considering which one of the two dominated in each grid cell (by considering the grid cells having more than $75 \%$ of coverage to be representative). For instance, from Figs. $3 \mathrm{c}$ and $4 \mathrm{c}$, the maximum percentage coverage for grassland is $32 \%$ for ORW and $36 \%$ for ARW, respectively, and it is assumed that $24 \%$ or more (i.e., $75 \%$ of the maximum) for ORW and $27 \%$ or more (i.e., $75 \%$ of the maximum) for ARW are considered predominantly grasslands. These transformations are indicated by the green patches in Fig. $3 \mathrm{~d}$ and the hatches in Fig. 4d. However, in case of the ORW, the grassland coverage that was predominant in the pre-dam persisted in the post-dam era (the 2003 LULC shown in Fig. 3d), hence, no transformation was required for it. For cropland,
$50 \%$ in grid cell or more for both regions was considered as predominant (Figs. $3 \mathrm{~b}$ and $4 \mathrm{~b}$ ). The pre-dam extents of the city of Sacramento downstream of Folsom Dam and Boise City downstream of Owyhee Dam are also included in the merged LULC representation.

Finally, merging procedure between the current land use and the reconstructed croplands and grasslands, as well as the urban regions was performed. The fact that there are only two broad classifications in the HYDE scheme (i.e., cropland and grassland) allows for the HYDE's $\sim 82 \mathrm{~km}^{2}(9 \mathrm{~km} \times 9 \mathrm{~km})$ grid extent to be merged with the fine-tuned (current) LULC used for the analysis. Tables 1 and 2 represent percentage coverage of the LULC classes in each of the considered scenarios along with the vegetation parameters for each class.

\subsection{Atmospheric model}

For this study, we used the RAMS (version 6.0). RAMS was developed to investigate cloud and land surface atmospheric phenomena and interactions, among other atmospheric 
Table 1. ORW: percentage coverage of the LULC classes in each of the considered scenarios and vegetation parameters for each LULC class (source: Walko and Tremback, 2005: Modification for the Transition from LEAF-2 to LEAF-3, ATMET technical note).

\begin{tabular}{|c|c|c|c|c|c|c|}
\hline \multirow[t]{2}{*}{ LULC-class name } & \multicolumn{3}{|c|}{ Percent area $(\%)$} & \multirow[t]{2}{*}{ Albedo } & \multirow[t]{2}{*}{ Emissivity } & \multirow{2}{*}{$\begin{array}{c}\text { Roughness } \\
\text { height, } Z_{\mathrm{o}} \\
(\mathrm{m})\end{array}$} \\
\hline & Pre-dam & Control & Non-irrigation & & & \\
\hline Urban and built up & 0.50 & 0.80 & 0.40 & 0.15 & 0.90 & 0.80 \\
\hline Evergreen needleleaf forest & 32.70 & 32.70 & 32.70 & 0.10 & 0.97 & 1.00 \\
\hline Deciduous needleleaf forest & 1.70 & 1.70 & 1.70 & 0.10 & 0.95 & 1.00 \\
\hline Deciduous broadleaf forest & 0.00 & 0.00 & 0.00 & 0.20 & 0.95 & 0.80 \\
\hline Evergreen broadleaf forest & 0.00 & 0.00 & 0.00 & 0.15 & 0.95 & 2.00 \\
\hline Closed shrubs & 2.70 & 2.70 & 2.70 & 0.10 & 0.97 & 0.14 \\
\hline Water & 0.50 & 0.60 & 0.50 & 0.14 & 0.99 & 0.00 \\
\hline Mixed forest & 0.60 & 0.60 & 0.60 & 0.14 & 0.95 & 0.40 \\
\hline Irrigated croplands & 13.20 & 14.7 & 10.0 & 0.18 & 0.95 & 0.06 \\
\hline Grasslands & 15.90 & 15.70 & 20.0 & 0.11 & 0.96 & 0.04 \\
\hline Savannas & 1.00 & 1.00 & 1.00 & 0.20 & 0.92 & 1.50 \\
\hline Barren or sparsely vegetated & 2.80 & 2.80 & 2.80 & 0.25 & 0.85 & 1.00 \\
\hline Woody savannas & 16.10 & 16.10 & 16.10 & 0.20 & 0.92 & 1.50 \\
\hline Open shrublands & 10.50 & 10.60 & 10.50 & 0.12 & 0.97 & 0.08 \\
\hline Crops, grass and shrubs & 0.50 & 0.80 & 0.40 & 0.25 & 0.92 & 0.14 \\
\hline
\end{tabular}

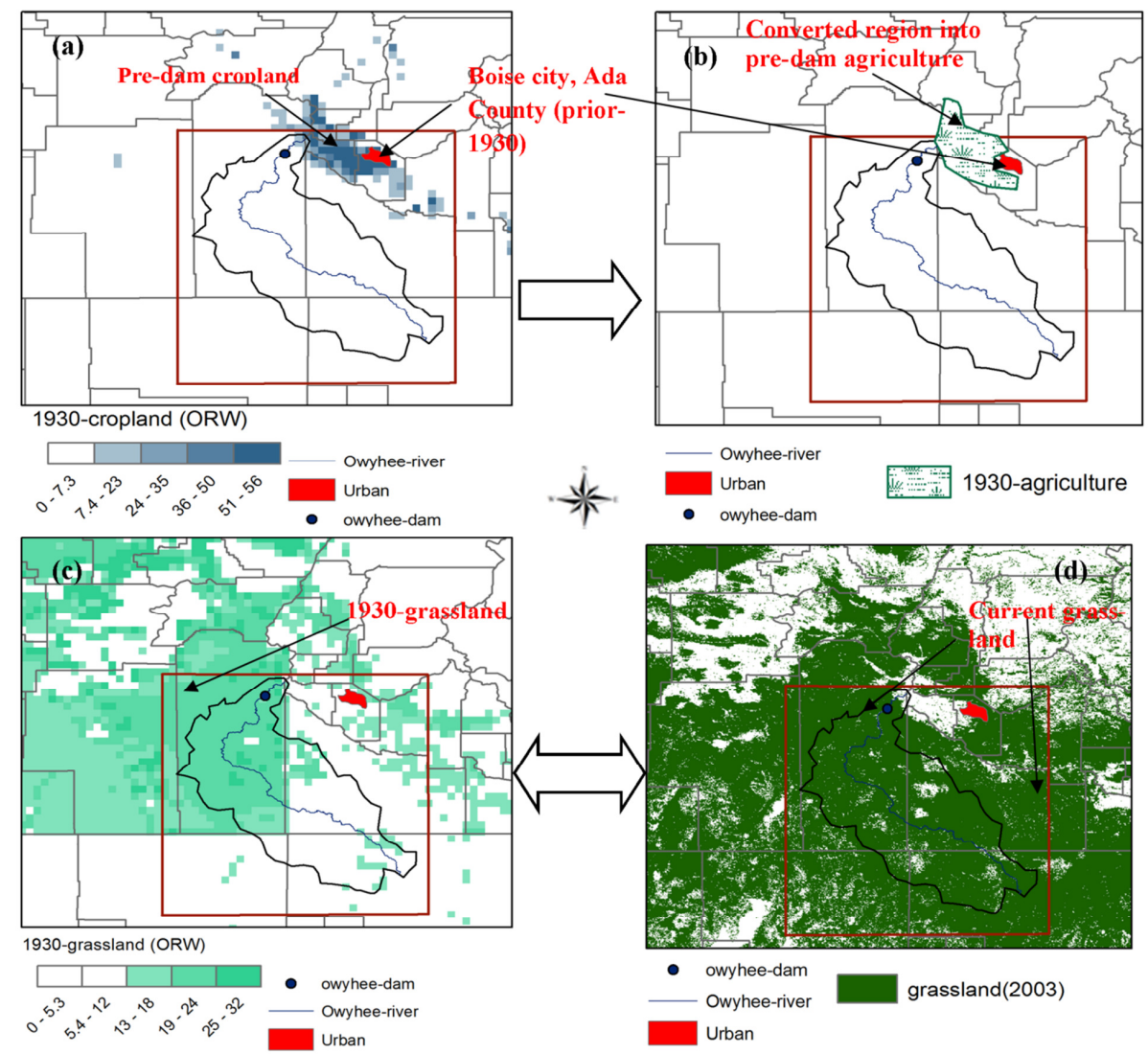

Figure 3. Percentage (\%) coverage of cropland and grassland over ORW (a, c), and derived croplands and grasslands for the 1930 pre-dam LULC analysis (b, d). Courtesy of the History Database of the Global Environment (HYDE) website (also available at http://themasites.pbl.nl). 
Table 2. ARW: percentage coverage of the LULC classes in each of the considered scenarios and vegetation parameters for each LULC class (source: Walko and Tremback, 2005: Modification for the Transition from LEAF-2 to LEAF-3, ATMET technical note).

\begin{tabular}{lllllll}
\hline LULC-class name & \multicolumn{3}{c}{ Percent area (\%) } & Albedo & Emissivity & $\begin{array}{c}\text { Roughness } \\
\text { height, } Z_{\mathrm{O}} \\
\end{array}$ \\
\cline { 2 - 5 } & Pre-dam & Control & Non-irrigation & & & 0.80 \\
\hline Urban and built up & 1.18 & 3.83 & 3.73 & 0.15 & 0.90 & 0.00 \\
Evergreen needleleaf forest & 26.75 & 27.69 & 27.44 & 0.10 & 0.97 & 1.00 \\
Deciduous needleleaf forest & 0.79 & 0.84 & 0.81 & 0.10 & 0.95 & 1.00 \\
Deciduous broadleaf forest & 0.002 & 0.002 & 0.002 & 0.20 & 0.95 & 0.80 \\
Evergreen broadleaf forest & 0.002 & 0.002 & 0.002 & 0.15 & 0.95 & 2.00 \\
Closed shrubs & 0.27 & 0.892 & 0.71 & 0.10 & 0.97 & 0.14 \\
Water & 0.26 & 1.79 & 1.69 & 0.14 & 0.99 & 0.00 \\
Mixed forest & 1.43 & 0.81 & 0.77 & 0.14 & 0.95 & 0.40 \\
Irrigated croplands & 0.68 & 21.42 & 2.77 & 0.18 & 0.95 & 0.06 \\
Grasslands & 25.16 & 8.23 & 7.34 & 0.11 & 0.96 & 0.04 \\
Savannas & 2.56 & 1.91 & 1.73 & 0.20 & 0.92 & 1.50 \\
Barren or sparsely vegetated & 0.33 & 0.06 & 0.04 & 0.25 & 0.85 & 1.00 \\
Woody savannas & 17.94 & 31.80 & 52.28 & 0.20 & 0.92 & 1.50 \\
Open shrublands & 0.65 & 0.68 & 0.67 & 0.12 & 0.97 & 0.08 \\
Crops, grass and shrubs & 22.12 & - & 0.001 & 0.25 & 0.92 & 0.14 \\
\hline
\end{tabular}
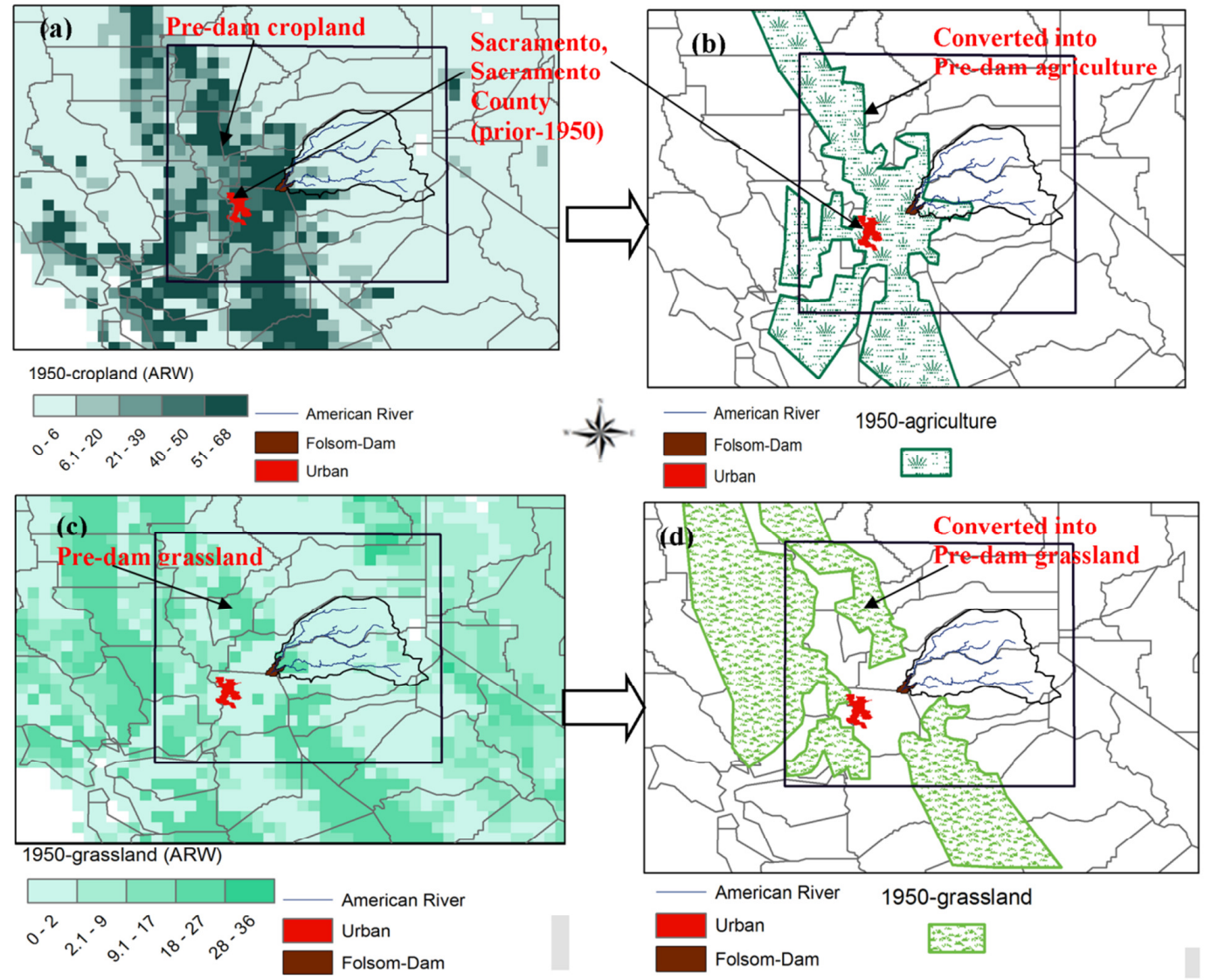

Figure 4. Percentage (\%) coverage of cropland and grassland over ARW (a, c), and derived croplands and grasslands for the 1950 pre-dam LULC analysis (b, d). Courtesy of the History Database of the Global Environment (HYDE) website (also available at http://themasites.pbl.nl). 
weather features (Pielke Sr., 1992; Tremback et al., 1985). RAMS is most often used as a limited area model, and many of its parameterizations have been formulated for highresolution mesoscale grids. The model has been extensively used to model detailed land-use descriptions and various land-use scenarios and their interactions with the atmosphere (Pasqui et al., 2000; Douglas et al., 2009; Woldemichael et al., 2012, 2013).

The grid domains used for this study are shown in Fig. 1. In both regions, a nested grid configuration was adopted. In ARW, the coarser grid (Grid-1) consisted of $60 \times 40$ grid points at $10 \mathrm{~km}$ intervals and it covered much of the northern California, part of western Nevada and small portion of the eastern Pacific Ocean. The nested grid (Grid-2) had $62 \times 62$ grid points spaced at $3.3 \mathrm{~km}$ intervals and covered all of the ARW. In ORW, the coarser grid (Grid-1) consisted of $66 \times 66$ grid points at $10 \mathrm{~km}$ grid intervals and covered portions of Oregon, Idaho and Nevada. The nested grid (Grid-2) consisted of $86 \times 86$ grid points at $3 \mathrm{~km}$ grid intervals and falls over the ORW. In both regions, 30 vertical levels were assigned with a vertical grid spacing of $100 \mathrm{~m}$ at the ground. The grid/stretch ratio used was 1.15 up to $1.5 \mathrm{~km}$ and kept constant from there on up to the model top. In both cases, a 20 s time step was set for the Grid-1 and a $5 \mathrm{~s}$ for Grid-2.

In order to represent the land-atmosphere interaction in the model, the recent version of the Land-EcosystemAtmosphere Feedback model (LEAF-3) was used (Walko and Tremback, 2002). Accordingly, 11 soil layers, 1 snow layer and 10 patches per grid cell for vegetation were assigned. The level-3 cloud microphysics scheme was adopted for this study (Meyers et al., 1997). Lateral boundary condition was represented by the Klemp and Wilhelmson scheme (Klemp and Wilhelmson, 1978).

Through a set of ensemble experiments for both regions (not shown here), a combination of cumulus parameterization and radiative schemes that best represent an observed spatial precipitation pattern were selected. These results were independently reported in the works of Woldemichael et al. (2012) for ARW and Woldemichael et al. (2013) for ORW, and the reader is encouraged to refer to those works. Accordingly, the short- and long-wave radiative transfer parameterization for both regions was furnished through the Harrington scheme (Harrington, 1997). The Kain and Fritsch (1993) convective parameterization was used for deep cumulus clouds in ORW, while the Kuo parameterization scheme was adopted for ARW (Kuo, 1974). The reason for using the relatively old Kuo parameterization for ARW was based on previous works of Castro (2005), which suggested that the Kain-Fritsch scheme generally overestimated precipitation in steep topography regions.

The inputs for RAMS model initialization were furnished by the National Center for Environmental Prediction/National Center for Atmospheric Research (NCEP/NCAR) reanalysis data (Kalnay, 1996). The surface characteristic data sets were obtained from the Atmospheric-
Meteorological and Environmental Technologies (ATMET) data archive (available at http://www.atmet.com). These data sets include digital elevation model (DEM) data at $30 \mathrm{~s}$ $(\sim 1 \mathrm{~km})$ spatial increments, soil moisture at various levels, the Normalized Difference Vegetation Index (NDVI), sea surface temperature (SST) and LULC.

\section{Results and discussion}

The surface and atmospheric analyses presented hereafter discuss the results obtained in the land-atmosphere interaction and related atmospheric dynamical processes. These analyses were done in the context of actual dam-induced LULC evolution that occurred in the study regions. They also discuss the link between surface-energy budget changes with the mesoscale convection initiation and observed heavystorm system in the study period. Atmospheric fields were updated at every $6 \mathrm{~h}$ interval based on the availability of the NCEP/NCAR reanalysis data. For the purpose of nudging the simulated values to the observed ones and, hence, removing any undesirable model drift, 4-dimensional data assimilation (4DDA) was activated in the model. To analyze the impact of LULC changes related to the presence of dams, a selected 6-day period (29 December 1996 to 3 January 1997) during the winter was primarily used. This period corresponds to an exceptional heavy-rain episode over both regions, and was responsible for causing devastating flooding and property damage. The accumulated 6-day precipitation amount for both regions is shown in Fig. 1 (lower panel).

As an initial step, the RAMS simulations were validated with respect to the Parameter-Elevation Regressions on Independent Slope Model (PRISM)-generated spatial monthly averages of maximum, minimum and dew-point temperature. The validation period was December 1996. PRISM (available at http://prism.oregonstate.edu) uses point data, a digital elevation model (DEM) and other sets of spatial data sets to generate gridded monthly and annual precipitation, maximum and minimum temperature and dew-point temperature on a $4 \mathrm{~km}$ spatial grid (Daly et al. 1994). The comparison between the PRISM generated monthly averaged minimum, maximum temperatures $\left({ }^{\circ} \mathrm{C}\right)$ and dew-point temperature $\left({ }^{\circ} \mathrm{C}\right)$, and the RAMS simulated values are shown on Fig. 5 for both ARW and ORW. The RAMS simulations, in most cases, follow the spatial patterns generated by PRISM, especially in the northeastern locations. The RAMS simulated values for ORW, however, are more widely spread than the PRISM values that are more detailed. These could be due to scale variations between the RAMS $(10 \mathrm{~km})$ and PRISM $(4 \mathrm{~km})$. In the case of ARW, since the scales of the PRISM and RAMS at the calibration runs was $4 \mathrm{~km}$ and $3 \mathrm{~km}$, respectively, there is a better spatial similarity in the simulated and observed temperature values between the two.

In addition to spatial comparisons, further validation was performed with radiosonde archives from NOAA Earth 


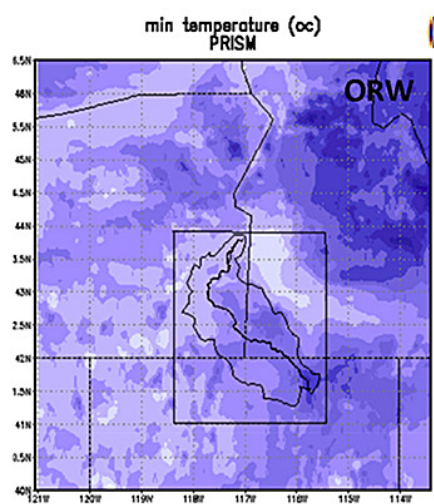

(a)
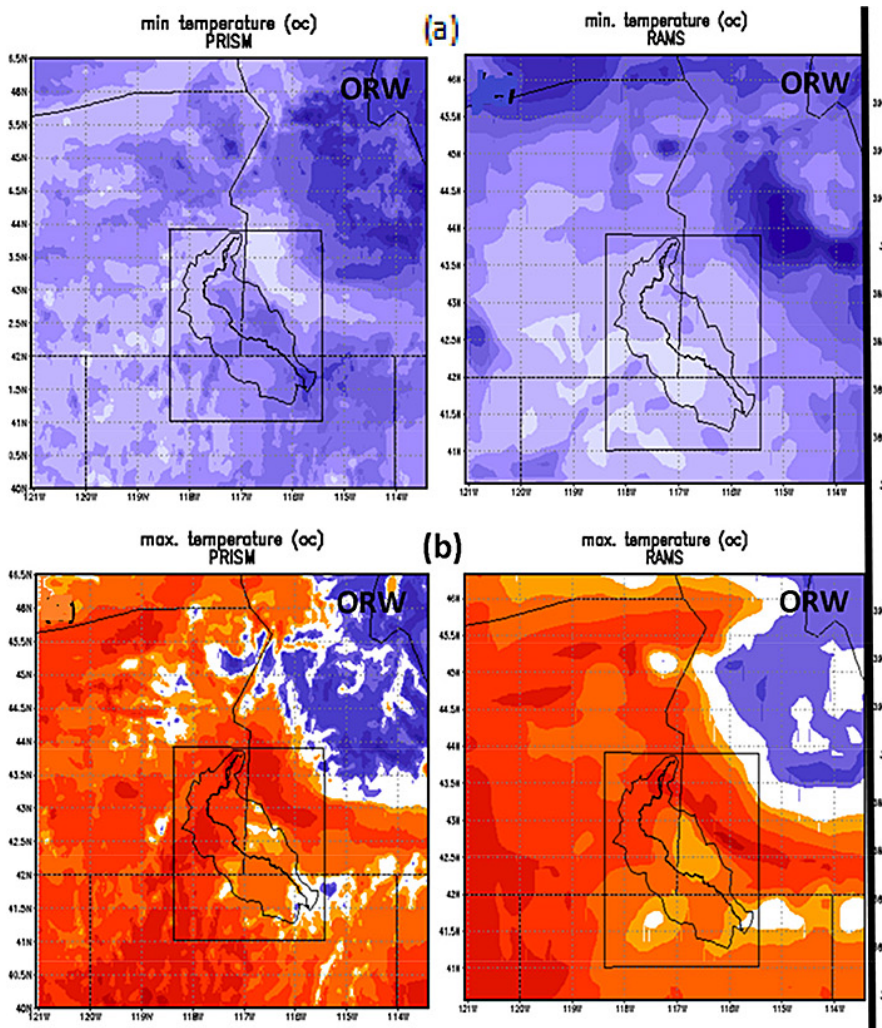

(b)
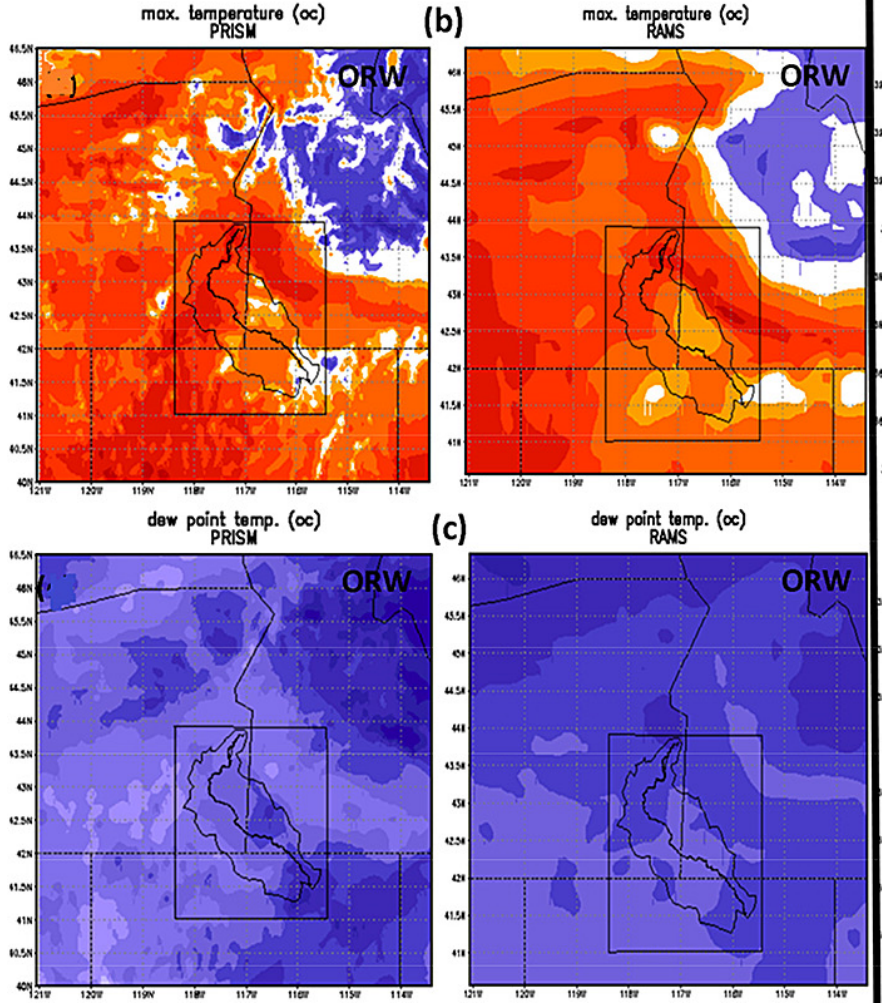

(c)

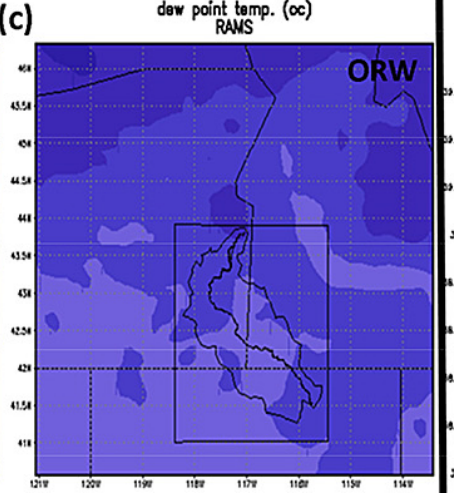

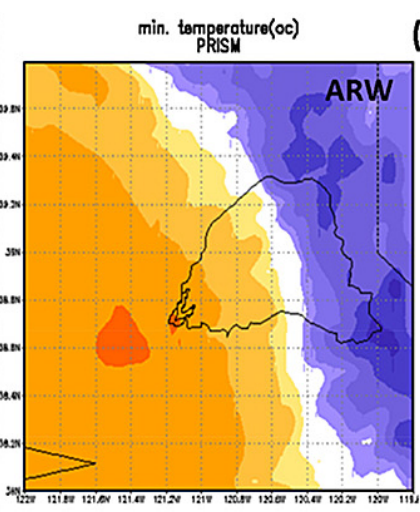

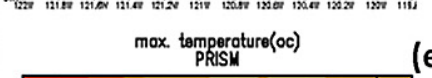

max. tomperature $(\propto)$

dour point temp. $(\infty)$ (d)

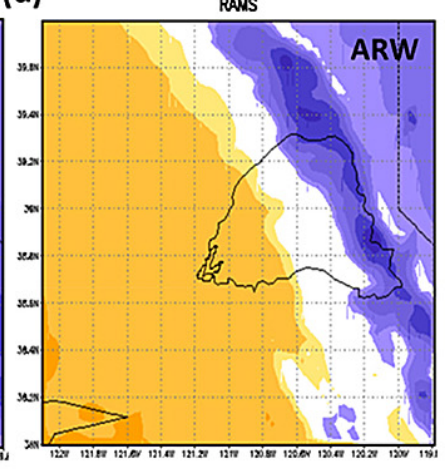

(e)

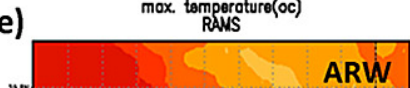

Figure 5. PRISM generated (left panels of a-f) and RAMS simulated (right panels of a-to-f) for ORW minimum, maximum and dew-point temperature (a, $\mathbf{b}$ and $\mathbf{c}$, respectively), and for ARW minimum, maximum and dew-point temperature (d, e and $\mathbf{f}$, respectively). All units are in ${ }^{\circ} \mathrm{C}$.

System Research Laboratory (ESRL) Global System Division (GSD) for certain locations in the ARW and ORW for the period of 1996-1997. Figure 6 presents the radiosonde station archives versus the RAMS-simulation results for 1 January 1997. The radiosonde soundings paint a clear picture of the existing atmospheric processes. At the Oakland location (Fig. 6a), since the elevation was only $6 \mathrm{~m}$ above sea level, the observed and simulated pressure at the lowest point is approximately $1000 \mathrm{mb}$ at all times. The simulated wind vectors showed similar directions as that of the simulations. However, the wind vectors from the observations had higher magnitudes. There were abrupt decreases in temper- ature readings at about 750,250 and $450 \mathrm{mb}$ of the observations which were not present in the simulation. Temperature inversions occurred at about $200 \mathrm{mb}$ for the observations, while the RAMS simulations showed temperature inversions at about $250 \mathrm{mb}$ levels. At the Reno, Nevada, station (Fig. 6b), the temperature inversions and other vertical profile characteristics are quite similar for the observation and simulated soundings. At a level of about $700 \mathrm{mb}$, the temperature and dew-point soundings become equal, indicating saturation. At Elko Station in ORW (Fig. 6c), the observations indicate saturation at $600 \mathrm{mb}$ level, which was not captured by the simulated soundings. At Boise Station (Fig. 6d), the 

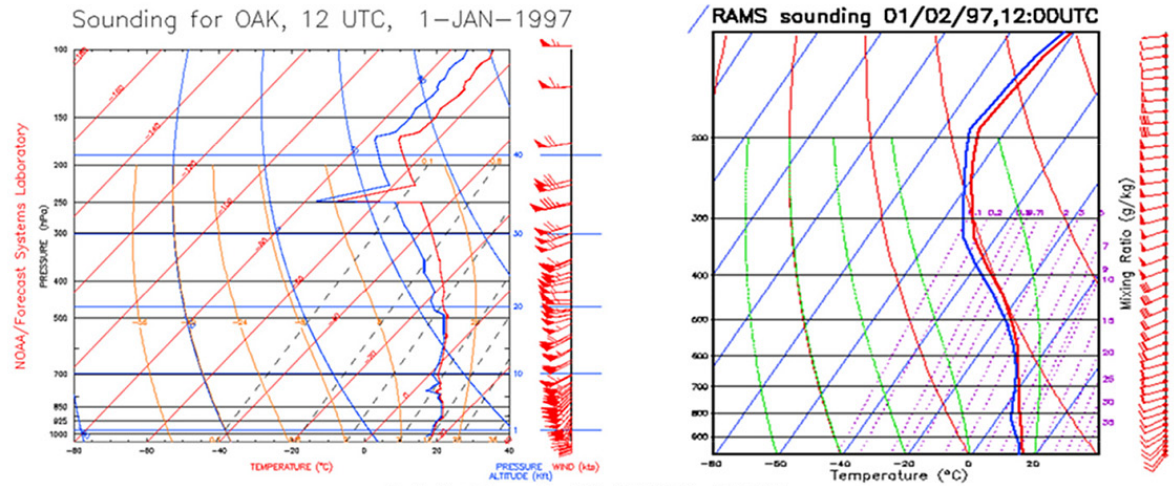

(a) Oakland, CA (OAK) -ARW
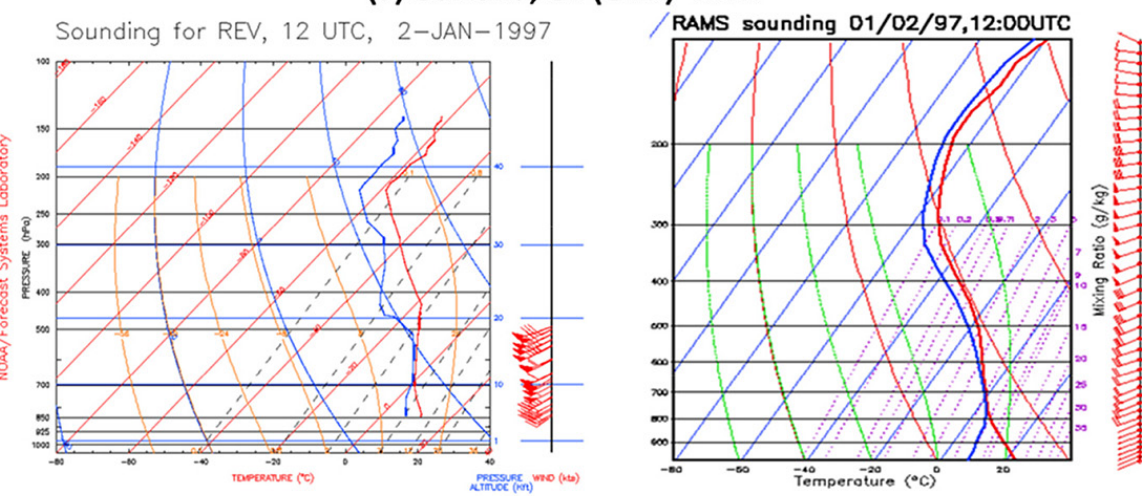

(b) Reno, NV (REV) -ARW
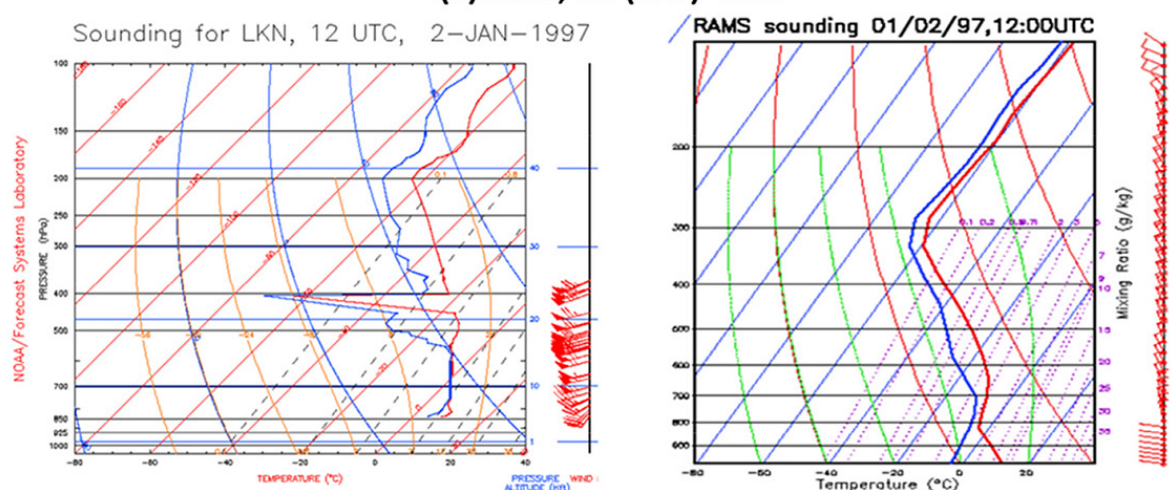

(c) Elko, NV(LKN) -ORW
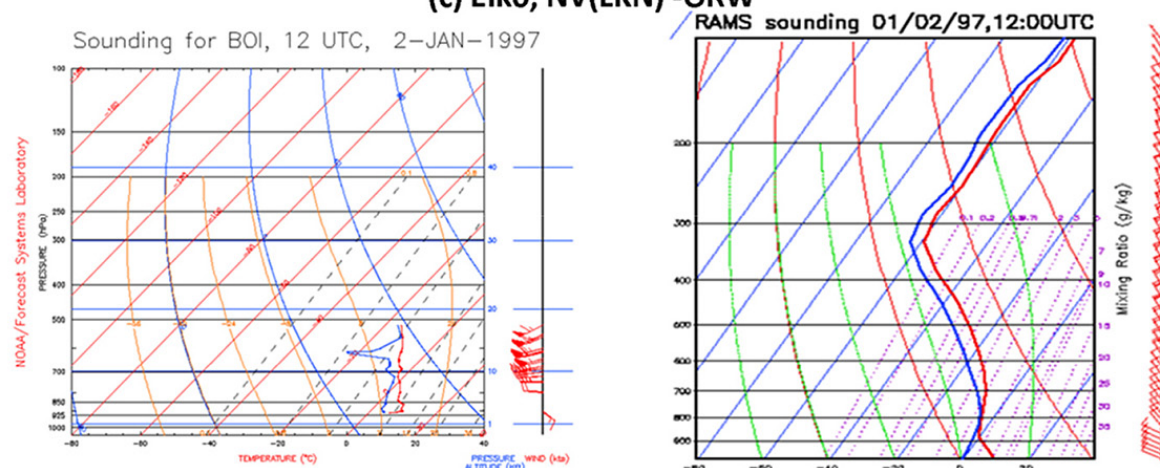

(d) Boise, OR(BOI) -ORW

Figure 6. Temperature soundings (red) and dew-point soundings (blue) from NOAA radiosonde observations taken at 12:00 UTC, 1 January 1997 (left panel) and generated from RAMS simulations for the same time period (right panel). The respective latitude and longitude of the locations is shown in Fig. 1. 
temperature difference: control - non-irr (oc)
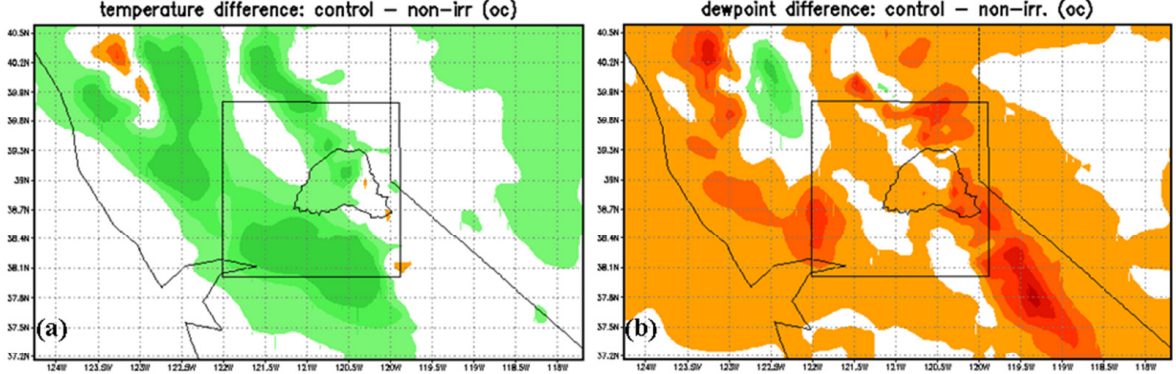

temperature difference: control - pre-dam (oc)

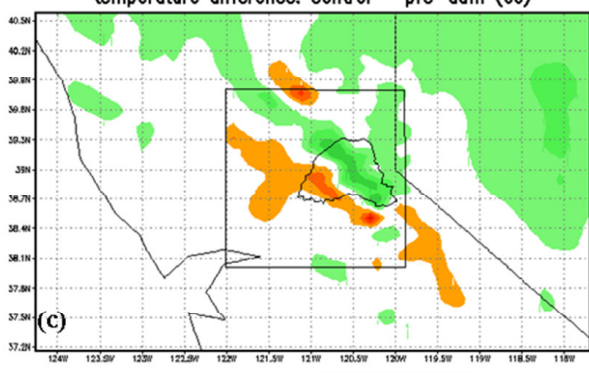

dewpoint difference: control - pre-dam (oc)
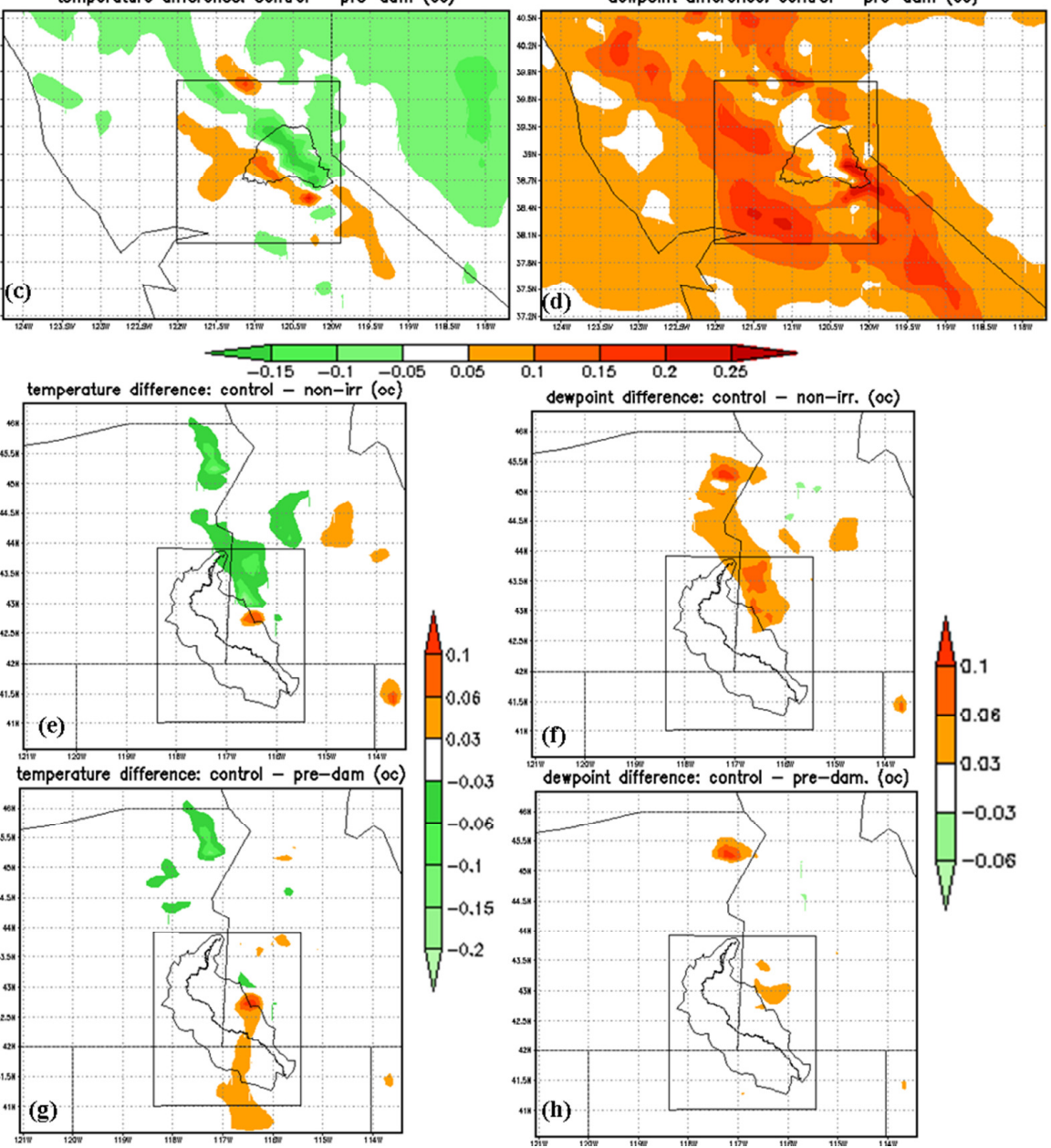

Figure 7. Differences in surface temperature $\left({ }^{\circ} \mathrm{C}\right)$ : $(\mathbf{a}, \mathbf{e})$ for control-non-irrigation for $A R W$ and ORW, respectively. $(\mathbf{c}, \mathbf{g})$ for controlpre-dam for ARW and ORW, respectively. Differences in dew point temperature $\left({ }^{\circ} \mathrm{C}\right)$ : $(\mathbf{b}, \mathbf{f})$ for control-non-irrigation for ARW and ORW, respectively. (d, h) for control-pre-dam for ARW and ORW, respectively.

observation soundings assume saturation between 600 and $700 \mathrm{mb}$. However, saturation was not observed for the simulated soundings. In summary, from Fig. 6 , it can be deduced that all the important vertical profile characteristics are adequately captured by the RAMS simulations.

\subsection{Surface analysis}

The lowest model level $(1000 \mathrm{mb})$ temperature averaged during the day over the heavy-storm episode in ARW was seen to be lower (up to $0.15^{\circ} \mathrm{C}$ ) for most of the domain in the control (or with the current irrigation) case as compared to the non-irrigation case, as shown in Fig. 7a. The decrease in the temperature corresponded to the regions where irrigation was intensified, indicating (expectedly) that irrigation 
had a tendency to suppress surface temperature and cause regional cooling. However, the pre-dam scenario showed little difference in temperature from the control, as shown in Fig. 7c. In fact, the control was seen to be warmer than the pre-dam at the downstream of Folsom Dam. This is perhaps due to the fact that much of the downstream area of Folsom was urbanized and the urban-heat island effect was likely dominant, causing a much warmer surface environment than the pre-dam settlement. In case of ORW, although both the control-non-irrigation and control-pre-dam differences were relatively small; the temperature was found to be lower and coincided with the region in which irrigation had been introduced.

The dew point was seen to be higher in the control (up to $0.25{ }^{\circ} \mathrm{C}$ over the heavy-storm episode period) than the non-irrigation, as well as for the pre-dam, as shown in Figs. $7 b, d, f$ and $h$. The result clearly indicated that irrigated agriculture created higher dew points provided that crops transpire and water applications were more frequent. This result also agrees with the findings of Mahmood et al. (2007) who evaluated dew-point temperature increases as a result of land-use change. In areas where natural landscape was converted to irrigated agriculture, as already previously observed, the near-surface air temperature was changed (Karl et al., 2012; Fall et al., 2010). These transformations have been seen to increase the dew-point temperature as it was observed in California's central valley, which was converted from natural vegetation to agriculture (Sleeter, 2008).

In order to see how significant the simulated changes in temperature and dew point were among the different scenarios, we calculated a statistical significance test using a $t$ test. The results of the significance tests are shown in Fig. 8. The figure presented the 85,90 and $95 \%$ statistical significance levels, shaded from light green to dark green. In general, statistically significant temperature and dew-point changes occurred over areas where LULC was changed. More prominently, in the ARW control-non-irrigation case (Fig. 8a), the areas of significant changes of temperature correspond to the areas of maximum irrigation to non-irrigation transformation. Also, in ORW, the slight observed changes are statistically significant, although the amounts of the changes are minimal. Temperature increase in the ORW, control-pre-dam case was also statistically significant, as observed in Fig. 8g. all in all, the simulation differences observed in the scenarios were found to be significant to an acceptable level.

It is understood that transformation of a non-irrigated region into irrigated agriculture results in the partitioning of sensible heat and latent heat, and, hence, affects the surfaceenergy balance (Mahmood et al., 2007). It also results in reduction of mean daily temperature, as shown in Fig. 9. An increase in soil moisture, as a result of irrigation, decreases the sensible heat while increasing the latent heat with respect to the control case. Figures $9 \mathrm{a}-\mathrm{h}$ compared the energy fluxes for all the scenarios in ARW and ORW. The LULC transformation from the pre-dam to the control appeared to have a limited effect both on ARW and ORW, as far as areal extent was concerned (Figs. 9b, d, f and h). In the inner grids of ARW sensible heat increased up to $21 \mathrm{~W} \mathrm{~m}^{-2}$ and latent heat decreased on the order of more than $10 \mathrm{~W} \mathrm{~m}^{-2}$.

The ARW region experienced a change of cropland into irrigated cropland (rain-fed) in the post-dam era. The albedo and the roughness height (Table 2) were similar for these two land uses. Pitman (2003) pointed out that changes in roughness height play a prominent role in variations in sensible and latent heat fluxes. The majority of the land use in ORW, on the other hand, remained the same (i.e., grassland: Fig. 3) for most of the domain and, as a result, showed only a slight variability both in the sensible, as well as latent, heat. On the contrary, the change from non-irrigation to control has resulted in a larger spatial variability of the energy fluxes. In ARW, the exact locations, where the previously irrigated land was converted to the nearest land-use pattern (i.e., woody savanna) in the control-non-irrigation case, showed a decrease in the sensible heat flux on the order of $15 \mathrm{~W} \mathrm{~m}^{-2}$ or greater. The decrease in sensible heat flux can be due to the hypothetical replacement of the woody savanna in the non-irrigation scenario with the existing cropland in the control. Crops transpire more due to their lower stomatal resistance and increased evapotranspiration. This intern cooled the surface, as shown in Fig. 7, and hence reduced the outgoing radiation in the form of sensible heat flux. An exception was the Sacramento urbanized region, where the sensible heat flux was greater due to the UHI effect. Inversely, the latent heat increased up to $10 \mathrm{~W} \mathrm{~m}^{-2}$ in the converted regions.

The combined comparison between sensible heat and the amount of latent heat is often essential in the energy balance determination. The comparison is usually made with the help of the Bowen ratio that represents the ratio between sensible and latent heat. In the ORW region, due to its arid nature and the fact that only a small portion was under irrigation, the Bowen ratio was seen to be much higher as compared to the ARW, which had a more humid climate and where much of the downstream area was in active irrigation. Figures 10a-f present the Bowen ratio for ARW and ORW. Comparison of the average Bowen ratio in each region revealed that it successively decreases from the non-irrigation to the pre-dam and to the control (Figs. 10a-f, respectively). This decrease was an indication that, as the land gets more irrigated due to the presence of the dam, the sensible heat diminishes, while all the available energy is converted into latent heat fluxes. A more significant transformation was observed in the change between the non-irrigation to control compared to the pre-dam to control results, due to it being less different in land-use change.

\subsection{Atmospheric-disturbance analysis}

The partitioning of surface energy into sensible and latent heat has been a major driver of atmospheric circulations and convection in most parts of the world (Pielke Sr., 2001). As 

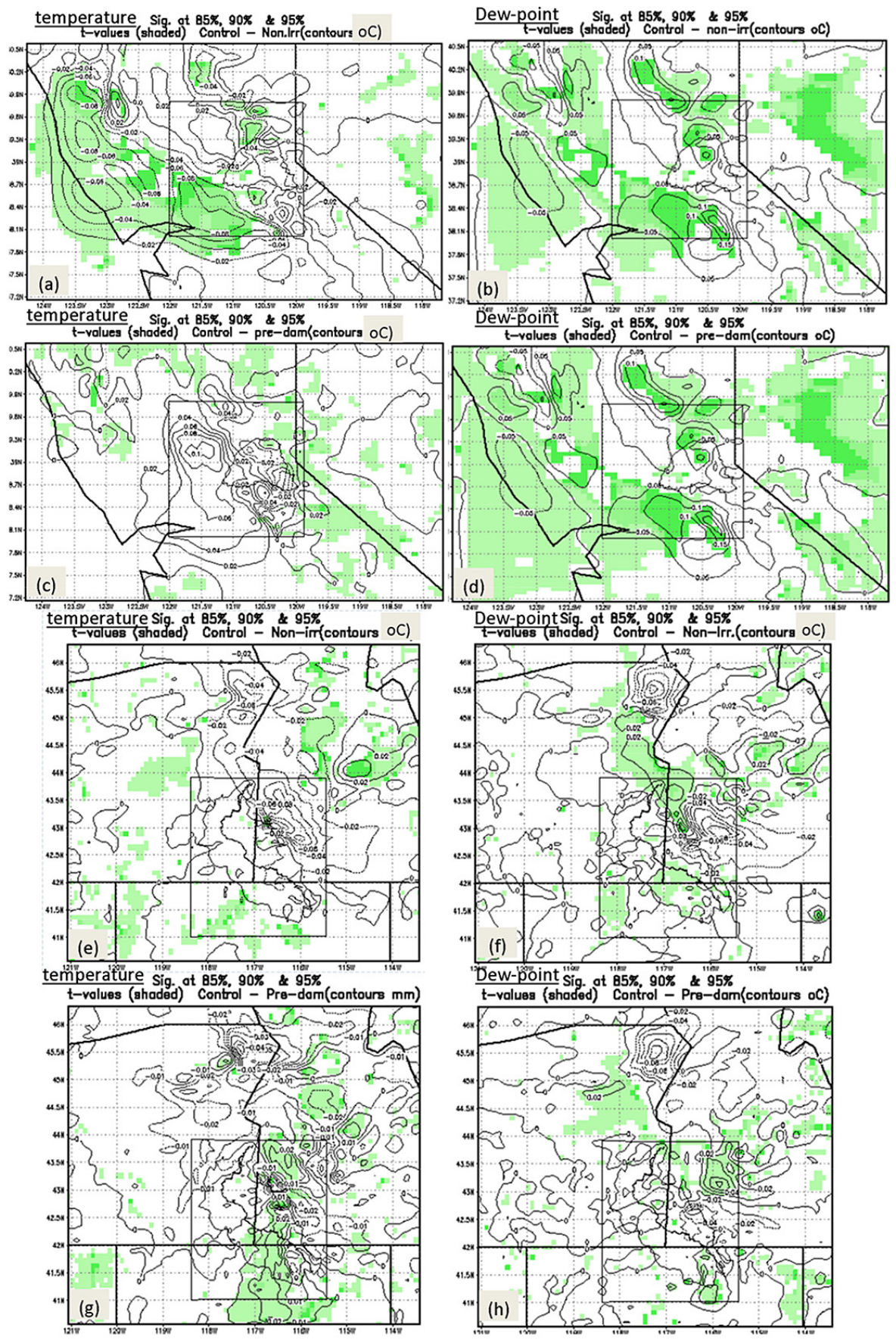

Figure 8. Statistical significance tests at confidence levels of 85,90 , and $95 \%$ from light to dark green for temperature and dew point. (a, e) for control-non-irrigation for ARW and ORW, respectively. (c, g) for control-pre-dam for ARW and ORW, respectively. Differences in dew-point temperature (oc): (b, f) for control-non-irrigation for ARW and ORW, respectively. (d, h) for control-pre-dam for ARW and ORW, respectively.

established in the previous section, small thermal gradients across the landscape and lower atmosphere were created due to the surface-energy budget variability. The low-level wind flow can also be affected as a result of the chain effects of LULC variability and resultants in creation of local horizontal pressure gradients.
In order to investigate the dam-induced anthropogenic changes of the wind flow, early-afternoon conditions at ARW and ORW were considered. Figures $11 \mathrm{a}-\mathrm{d}$ represent the averaged low-level (1000 mb level) atmospheric wind-speed and direction differences for both regions. Looking at the wind vectors closely, there were regions of convergence on the 

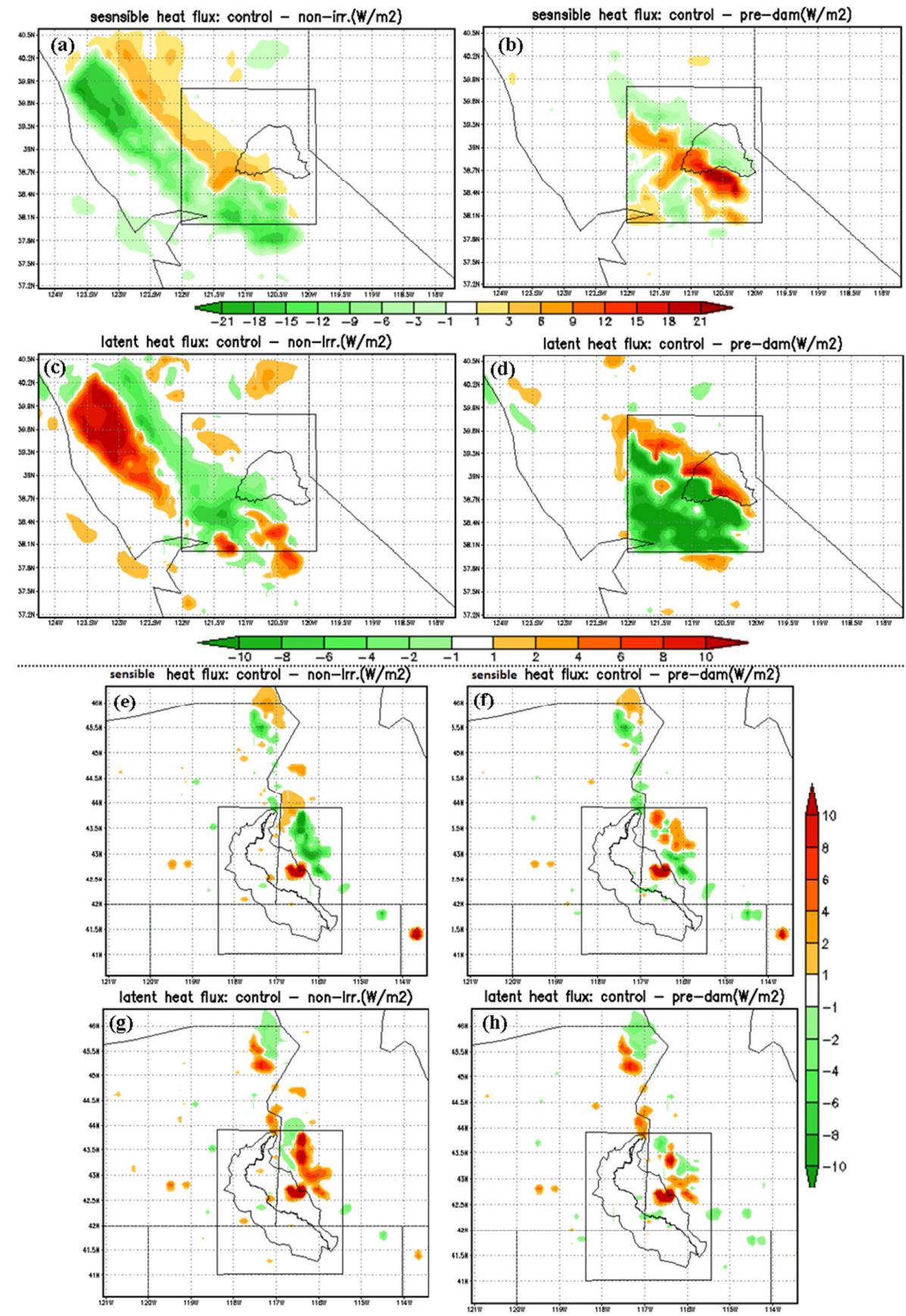

Figure 9. Differences in sensible and latent heat fluxes $\left(\mathrm{W} \mathrm{m}^{-2}\right)$. (a, b, e, f) Differences for ARW and ORW, sensible heat fluxes, respectively. $(\mathbf{c}, \mathbf{d}, \mathbf{g}, \mathbf{h})$ Differences for ARW and ORW latent heat fluxes, respectively.

northwestern end in ARW and northern end in ORW. In the ARW's control-non-irrigation scenario, the presence of irrigation has obviously increased the wind flow by an amount of $1.6 \mathrm{~m} \mathrm{~s}^{-1}$ or more in areas where land-cover change was introduced. This is due to the fact that a land-cover type characterized by larger roughness height (i.e., woody savanna with $Z_{\mathrm{o}}=1.5 \mathrm{~m}$, Table 2) in the non-irrigation case was converted into an irrigated cropland $\left(Z_{\mathrm{o}}=0.06 \mathrm{~m}\right)$ in the control case. The difference in the roughness height $\left(Z_{\mathrm{o}}\right)$ had clearly contributed to locally induced wind flows in the region.

The control-pre-dam scenario of the ARW, however, showed a reduction in the wind speed (up to $-1.4 \mathrm{~m} \mathrm{~s}^{-1}$ in magnitude) confined in a small area. The land-cover change, in this case, was characterized by the expansion of the city of Sacramento in the control case and the drag caused by buildings in cities was responsible in reducing the speed. In 

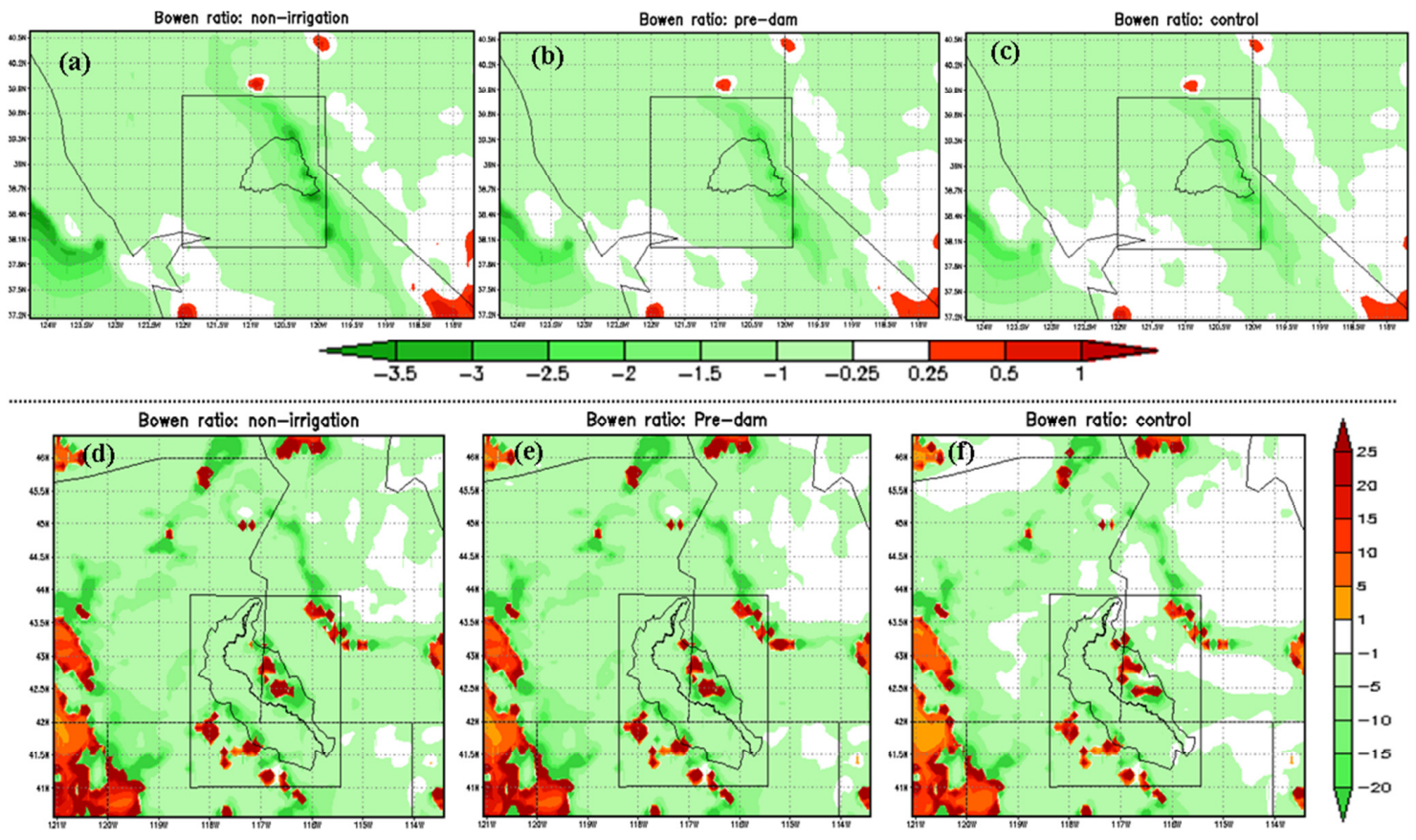

Figure 10. Bowen ratios for ARW top panel and ORW bottom panel, left to right, represent non-irrigation, pre-dam and control.

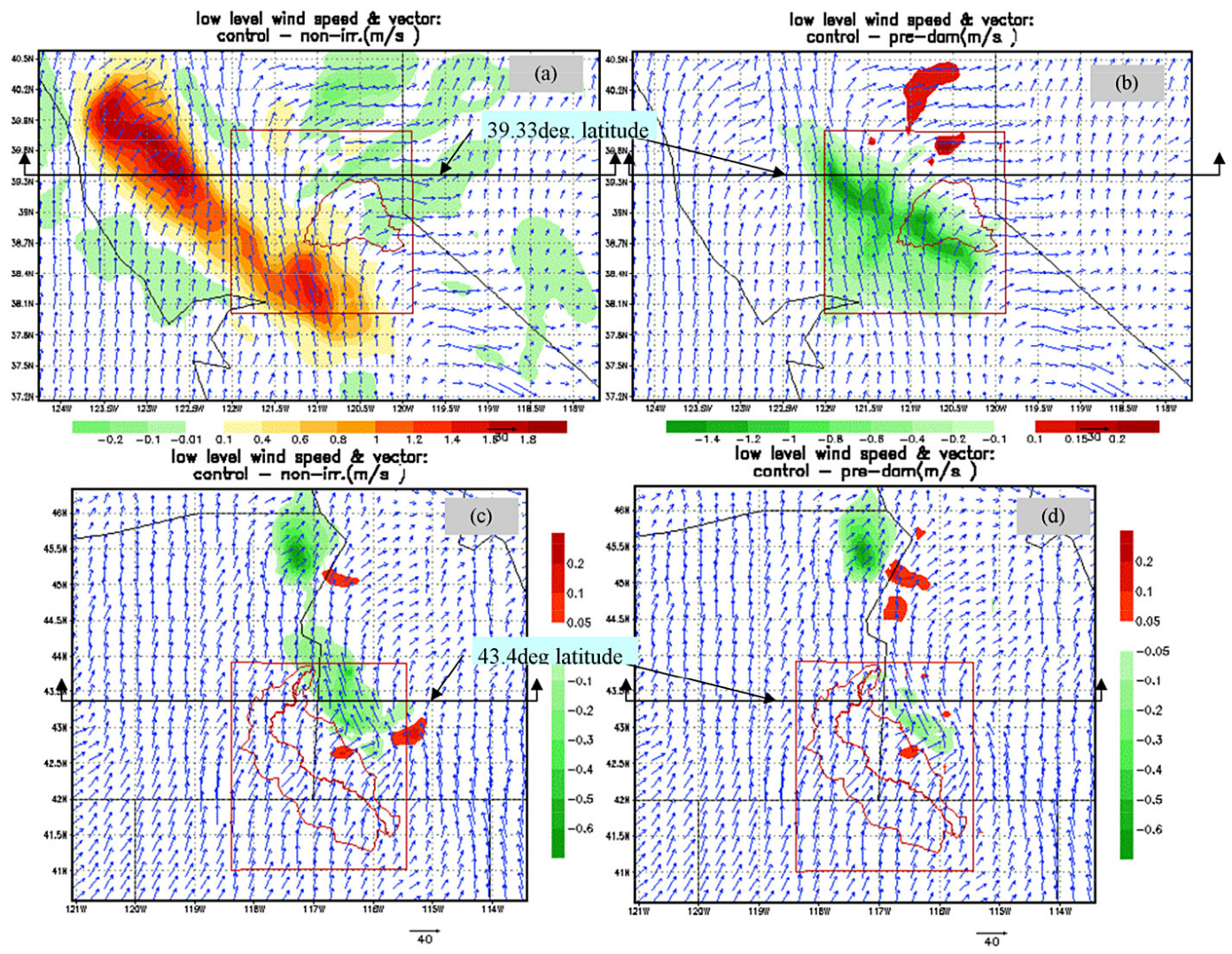

Figure 11. Low-level wind speed $\left(\mathrm{m} \mathrm{s}^{-1}\right)$ and vector. (a, b) for ARW, control-non-irrigation and control-pre-dam cases, respectively. (c, d) for ORW, control-non-irrigation and control-pre-dam cases, respectively. 

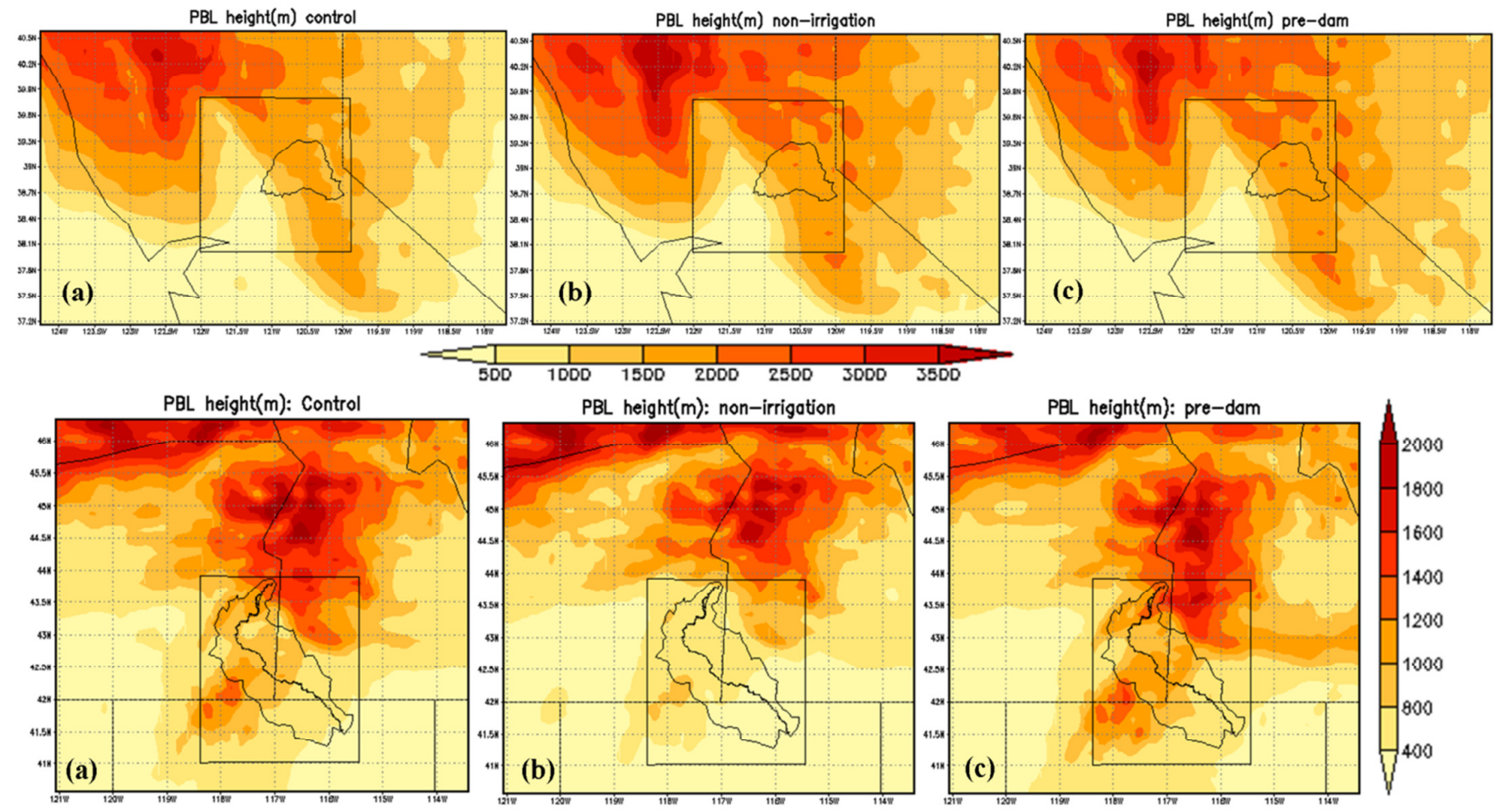

Figure 12. The average depth of PBL (m) for each scenario and region. Top panels $(\mathbf{a}, \mathbf{b}, \mathbf{c})$ represent control, non-irrigation and pre-dam for ARW while bottom panels $(\mathbf{a}, \mathbf{b}, \mathbf{c})$ represent control, non-irrigation and pre-dam for ORW.

ORW, a small area of convergence was observed in the inner grid at the northeastern location. The control seemed to have lower magnitudes of wind speed (up to $-0.4 \mathrm{~m} \mathrm{~s}^{-1}$ difference) from both the non-irrigation and pre-dam. The types of land-use transformations in both scenarios had a small difference in roughness height than the control. In case of nonirrigation, the irrigated cropland was converted into grassland (roughness height, $Z_{\mathrm{o}}=0.06$ and $0.04 \mathrm{~m}$, respectively, Table 1) while, in the case of the pre-dam, the predominant land-use type (i.e., grassland) remained unaltered for the majority of the area. However, the small area wind-speed difference observed in control-non-irrigation, as explained above, could be due to the drag effect resulting from the expansion of the city.

Another analysis was performed at the mid-level of the maximum depth of the planetary boundary layer (PBL). The average depth of the RAMS-generated PBL for each scenario, as well as region, is presented in Fig. 12. The mid-level PBL depth for ARW was at $1750 \mathrm{~m}$ above the ground, while, for ORW, it was at $1000 \mathrm{~m}$ above the ground. The respective wind magnitudes and directions midway through the PBL are shown in Figs. 13a-d. At this level, the convergence zones in ARW tend to disappear, unlike the wind directions noted on the low level. On the other hand, the convergence zones, where two prevailing wind flows meet and interact within ORW, still existed midway through the PBL, which indicates a stronger mesoscale circulation. These observations indi- cated that, in case of ARW, the changes observed in the latent and sensible heat fluxes influence only the lower-boundarylayer wind flow. However, in both cases, local and mesoscale upward motion regions resulted from the low-level convergence for both the ARW and ORW. This documents that the circulations due to LULC changes can transport moisture and heat higher into the atmosphere as discussed below.

The specific low-level convergence location selected for analysis was at $39.3^{\circ} \mathrm{N}$ latitude for $\mathrm{ARW}$ and $43.4^{\circ} \mathrm{N}$ latitude for ORW. These locations were consistent with the region where cool and moist air from the irrigated regions contrasted with relatively drier air from the nearby locations (indicated by the horizontal line in Fig. 11). Figures 14a$\mathrm{d}$ show the vertical cross section of simulated water-vapor mixing ratio differences from the lowest level up to the top of the PBL ( $3500 \mathrm{~m}$ for ARW and $2000 \mathrm{~m}$ for ORW) for the 6-day averages of 22:00 UTC (or 14:00 LST). Figures 14a and $\mathrm{b}$ are for ARW: control-non-irrigation and control-pre-dam, respectively. Both scenarios showed welldeveloped vertical motion that was responsible in transporting moisture from the surface to higher altitudes. For the control-non-irrigation, in particular, the 121 to $122.5^{\circ} \mathrm{W}$ longitudes, where the low-level wind convergence was observed (Fig. 11a); the circulation cells were maximum for the lower half of the PBL. However, as the convergence zone disappears, as shown in Fig. 13a, there is a discontinuity in the vertical circulation cells. The control-pre-dam scenario, on 

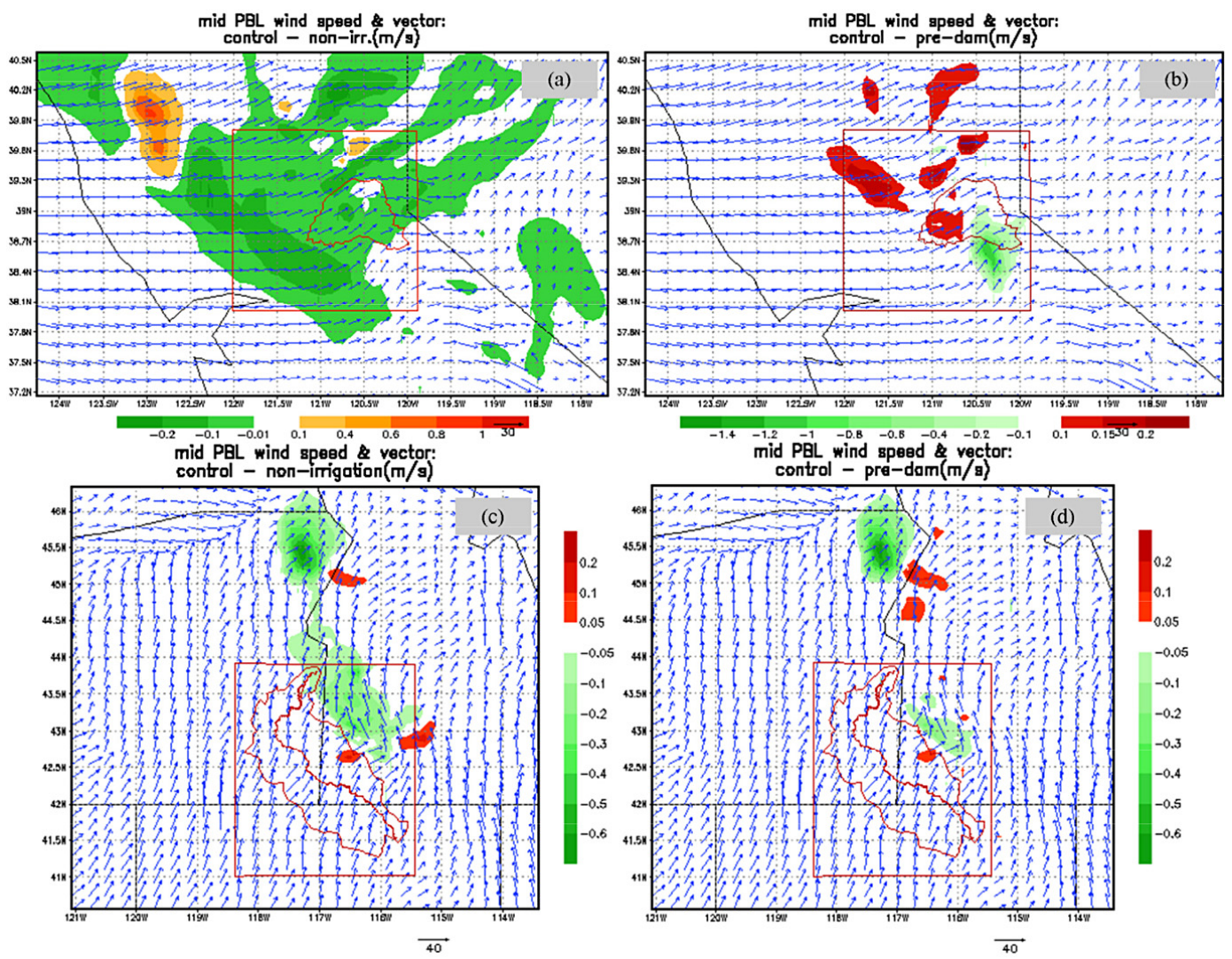

Figure 13. Mid-PBL wind speed $\left(\mathrm{m} \mathrm{s}^{-1}\right)$ and vector. (a, b) for ARW, control-non-irrigation and control-pre-dam cases, respectively. (c, d) for ORW, control-non-irrigation and control-pre-dam cases, respectively.

the other hand, manifested a different pattern, where there was no discontinuity throughout the whole depth of the PBL. Figures $14 \mathrm{~b}$ and $\mathrm{c}$ showed vertical cells for control-nonirrigation and control-pre-dam respectively. At longitudes of 116 to $117^{\circ} \mathrm{W}$, the convergence zones were fully established all the way through the top of the PBL. Correspondingly, the vertical water-vapor mixing cells traversed from the ground up to the top of the PBL in both cases. In this case, the moisture was transported much deeper than the PBL, indicating a much stronger vertical motion established in ORW than ARW. In both regions, the dense area of moisture transport corresponded to the location in which wind convergence occurred.

Finally, to understand the availability of potential energy and convective contribution for precipitation formation, a CAPE analysis, was performed. Figure 15 indicates the amounts of CAPE in the atmosphere for ARW and ORW, respectively, during the time of maximum CAPE (3 January 1997) out of the considered 6 days of analysis. Although the CAPE values were not large enough to warrant a convective initiation in the regions, there was a progressive increase in CAPE value from the pre-dam to the non-irrigation and to the control, mostly in the ARW. In all cases, the observed increase in CAPE originated from the increase in the latent heat flux in much of the northwest in ARW and eastern parts of ORW. There is also the important question as to how LULC affects these synoptically driven winter-time systems. Since positive CAPE is recognized as a major factor that is altered by LULC, yet, during most days in the winter in the study regions, there is no CAPE, the general impression is that LULC effects on precipitation cannot work in these situations.

However, during these synoptically driven rain events, CAPE is often quite positive. Severe thunderstorms [with documented strong convective instability] and even tornadoes occur during these events (e.g., Hanstrum et al., 2002; Kingsmill et al., 2006) (see also https://ams.confex.com/ams/ pdfpapers/115125.pdf). Our results indicated that, during these precipitation events, a significant fraction involves deep cumulus clouds, and thus changes in CAPE, and other thermodynamic aspects of the atmosphere by LULC, result in alterations in precipitation from what would otherwise have occurred.

In order to see how the CAPE varies among the different scenarios, CAPE differences between control and nonirrigation, as well as control and pre-dam, are shown in Fig. 16. Figure 16 represents the 6-day day-time average differences in CAPE. According to Pielke Sr. (2001), a larger fraction of energy partitioned to latent-heat-flux results in 

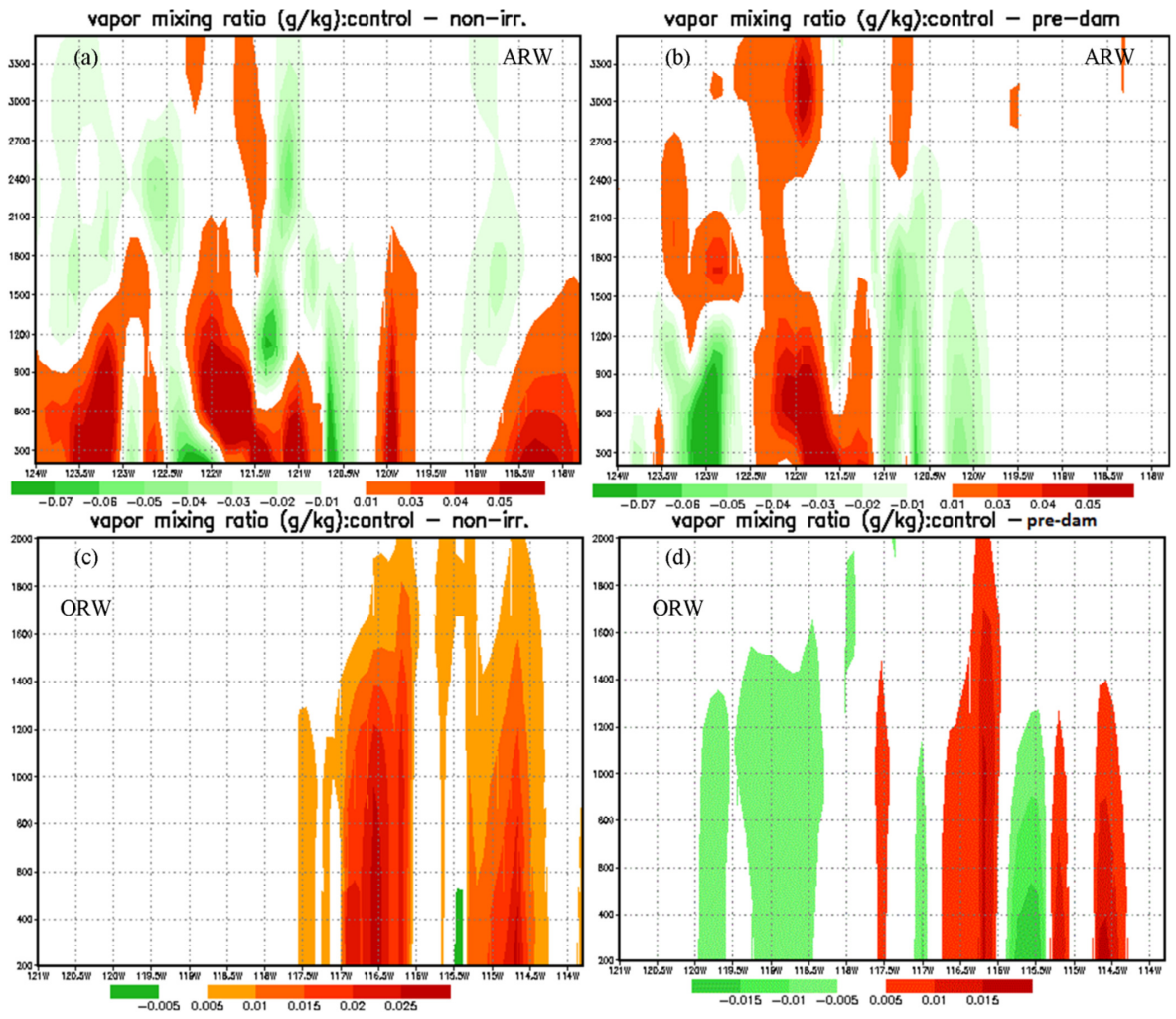

Figure 14. Altitude-longitude cross section of simulated vapor-mixing ratio $\left(\mathrm{g} \mathrm{kg}^{-1}\right)$. (a, b) for ARW (at $\left.39.330^{\circ} \mathrm{N}\right)$ and (c, d) for ORW (at $43.40^{\circ} \mathrm{N}$ ). All calculations are at 22:00 UTC (or 14:00 LST).

greater CAPE and added moisture to facilitate deep convection, provided that suitable conditions exist. Looking at Fig. 16, it is apparent that, in both regions, a larger CAPE is observed for the control, as compared to the nonirrigation and pre-dam. These larger CAPE values are especially prominent at locations in which irrigation was intensified. In non-irrigated regions, there is larger sensible heat flux that does not favor CAPE over the latent heat flux. On the contrary, irrigation will add significant latent heat flux resulting from transpiration of water vapor. For larger irrigated areas, there is a possibility of development of mesoscale circulation. However, as discussed previously in such synoptically driven regions as ARW and ORW, the possibility of CAPE being a factor for generating a storm is minimal.

\section{Summary and conclusions}

Precipitation is highly dependent on both the vertical and horizontal pathways of water-vapor flux. How dam-induced mesoscale-atmospheric changes in an impounded region impact these fluxes needs to be further understood. In this study, a number of more primitive variables that accompany heavy precipitation patterns were evaluated. The RAMS was set up to model two impounded regions with climatic and topographic contrasts: the Folsom Dam in ARW and the Owyhee
Dam in ORW. For each of these regions, three experimental LULC scenarios were established: (1) the control scenario, representing the contemporary land use, (2) the predam scenario, representing the natural landscape before the construction of the dams and (3) the non-irrigation scenario, representing the condition where previously irrigated landscape in the control is transformed to the nearby land-use type. Based on these scenarios, a differential LULC (i.e., control-non-irrigation and control-pre-dam) evaluation was performed to evaluate surface-energy changes and atmospheric disturbances.

From the point of view of locations, the ARW was found to be more sensitive to associated changes in energy and moisture fluxes than the ORW. This perhaps is due to the fact that the areal extent of LULC change in the ARW is much greater than that of the ORW. It was also reported in our previous work (Woldemichael et al., 2013) that the postdam LULC change scenarios impact precipitation of ORW (Owyhee Dam) much more than that of the ARW (Folsom Dam). We hypothesized that, due to its semi-arid climate and flat terrain, the ORW was very sensitive to even slight changes in the variables that lead to precipitation modification than for the ARW, which is in a humid climate and on mountainous terrain (Jeton et al., 1996; Vaccaro, 2002). 

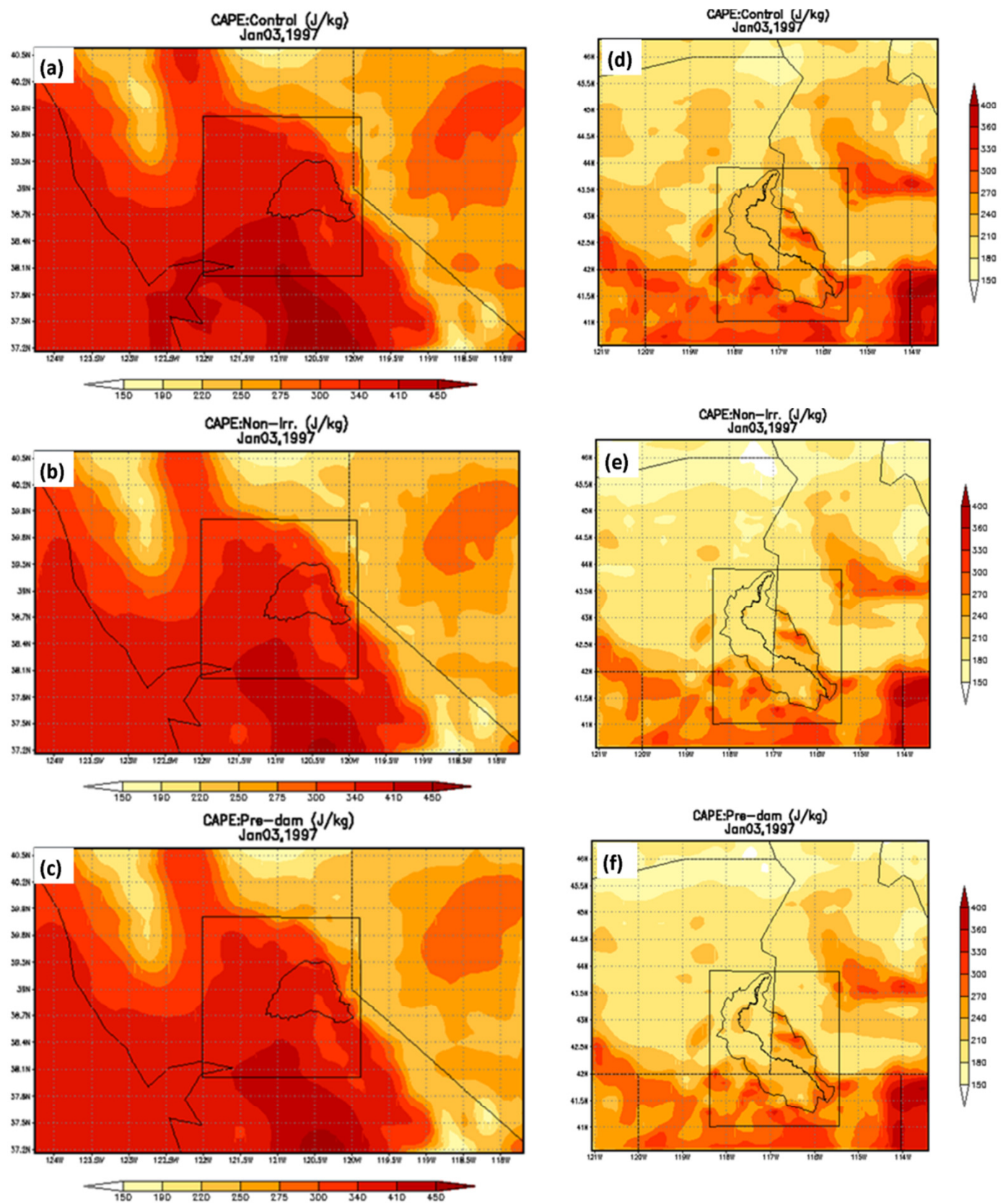

Figure 15. Daytime average Convective Available Potential Energy (CAPE, $\mathrm{J} \mathrm{kg}^{-1}$ ) for 3 January 1997 for ARW control, non-irrigation and pre-dam $(\mathbf{a}, \mathbf{b}, \mathbf{c})$, and ORW control, non-irrigation and pre-dam $(\mathbf{d}, \mathbf{e}, \mathbf{f})$.

However, both regions showed a strong link between the sensitivity of the surface-energy and moisture fluxes and precipitation in the LULC assessment. More prominently, the control-non-irrigation cases showed a much higher impact than the control-pre-dam conditions, which is perhaps because of larger roughness height $\left(Z_{\mathrm{o}}\right)$ differences in the previous case. Similarly, previous work indicated that precipitation modification was found to be much higher in the control-non-irrigation cases in ARW, as well as in ORW (Woldemichael et al., 2012). Both regions, however, dis- played atmospheric conditions for a significant modification in precipitation to occur: (1) the combination of a decrease in temperature (up to $0.15^{\circ} \mathrm{C}$ ) and an increase in dew point (up to $0.25^{\circ} \mathrm{C}$ ) was observed, (2) similar to the finds of Douglas et al. (2009), there is a larger fraction of energy partitioned to latent heat flux (up to $10 \mathrm{~W} \mathrm{~m}^{-2}$ ) that increases the amount of water-vapor flux into the atmosphere and result in a larger CAPE, (3) low-level wind-flow variation was found to be responsible in creating a pressure gradient that affects localized circulations and moisture advection and convergence. 

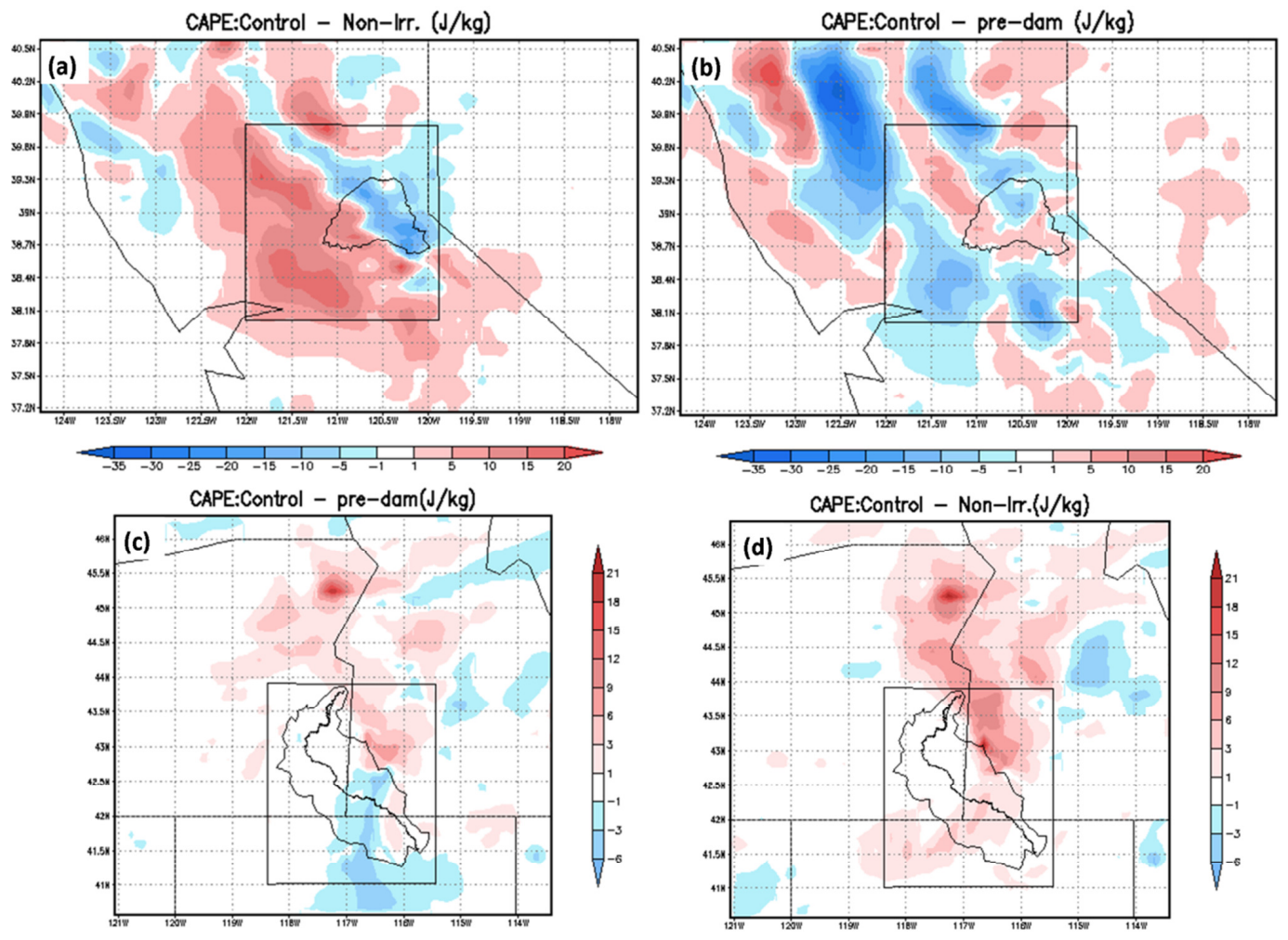

Figure 16. Differences in $C$ Convective Available Potential Energy (CAPE, $\mathrm{J} \mathrm{kg}^{-1}$ ) for ARW and ORW control-non-irrigation (a, b) and ARW and ORW control-pre-dam (b, c). Note that values are 6-day daytime averaged for 29 December 1996 to 3 January 1997.

An increase in wind speed up to $1.6 \mathrm{~m} \mathrm{~s}^{-1}$ maximum was simulated in the regions due to the chain effects of LULC variability, (4) there were well-developed vertical motions that can transport moisture from the surface to higher altitudes, and these were observed at locations where the precipitation difference was also a maximum. All of these findings further reinforced the fact that there is a strong correlation between the changes in surface and atmospheric properties, and corresponding resultant precipitation modification.

The 2003 Climate Change Science Program (2003) (CCSP 2003) proposed assessment strategies to understand how current and predicted changes in LULC will modify weather and climate. The report specifically mentioned that "assessment capabilities should include the means to evaluate the interactions of land use and management with climate change in a way that will help decision makers mitigate or adapt to the change." It was also mentioned that both climate systems and anthropogenic activities that result in LULC changes are complex processes. In this regard, this study has shed light on two important aspects: (1) the LULC alterations that result from dam construction, which is a new paradigm in the process of human-induced LULC change assessment, and (2) the distinctiveness of land-atmosphere interaction of dam-driven LULC changes as a function of location.
Acknowledgements. The first author was supported by a NASA Earth System Science (NESSF) fellowship grant (NNX12AN34H). The authors acknowledge the technical support received from Mike Renfro of the Computer-Aided Laboratory at the Center for Manufacturing Research, Tennessee Technological University, who helped in the efficient set up of the RAMS model on various computing clusters. R. A. Pielke Sr. received support through the Vice Chancellor for Research at the University of Colorado in Boulder (CIRES/ATOC) and from NSF Grant AGS-1219833.

Edited by: F. Laio

\section{References}

Betts, A. K., Ball, J. H., Beljaars A. C. M., Miller M. J., and Viterbo, P. A.: The land surface-atmosphere interaction: A review based on observational and global modeling perspectives, J. Geophys. Res., 101, 7209-7225, 1996.

Boucher, O., Myhre, G., and Myhre, A.: Direct human influence of irrigation on atmospheric water vapor and climate, Clim. Dynam., 22, 597-603, doi:10.1007/s00382-004-0402-4, 2004.

Castro, C. L.: Investigation of the summer climate of North America: A regional atmospheric modeling study, $\mathrm{Ph} . \mathrm{D}$. dissertation, Colo. State Univ., Fort Collins, 2005. 
Climate Change Science Program: Strategic plan for the U.S. climate change science program: Washington, D.C., p. 202, also available online at: http://purl.access.gpo.gov/GPO/LPS64573 (last access: 2 July 2013), 2003.

DeAngelis, A., Dominguez, F., Fan, Y., Robock, A., Kustu, M. D., and Robinson, D.: Evidence of enhanced precipitation due to irrigation over the Great Plains of the United States, J. Geophys. Res., 115, 787 D15115, doi:10.1029/2010JD013892, 2010.

Degu, A. M. and Hossain, F.: Investigating the mesoscale impact of artificial reservoirs on frequency of rain during growing season, Water Resour. Res., 48, W05510, doi:10.1029/2011WR010966, 2012.

Dettinger, M. D., Ralph, F. M., Hughes, M., Neiman, T. D. P., Cox, D., Estes, G., Reynolds, D., Hartman, R., Cayan, D., and Jones, L.: Design of quantification of an extreme winter storm scenarios for emergency preparedness and planning exercise in California, Nat. Hazards, 60, 1085-1111, doi:10.1007/s11069-011-9894-5, 2012

Douglas, E. M., Niyogi, D., Frolking, S., Yeluripati, J. B., Pielke Sr., R. A., Niyogi, N., Vörösmarty, C. J., and Mohanty, U. C.: Changes in moisture and energy fluxes due to agricultural land use and irrigation in the Indian Monsoon Belt, Geophys. Res. Lett., 33, L14403, doi:10.1029/2006GL026550, 2006.

Douglas, E. M., Beltran, A., Niyogi, D., Pielke Sr., R. A., and Vorosmarty, C. J.: The impact of agricultural intensification and irrigation on land atmosphere interactions and Indian monsoon precipitation - A mesoscale modeling perspective, Global Planet. Change, 67, 117-128, doi:10.1016/j.gloplacha.2008.12.007, 2009.

Eungul, L., Sacks, W. J., Chase, T. N., and Foley, J. A.: Simulated impacts of irrigation on the atmospheric circulation over Asia, J. Geophys. Res., 116, D08114, doi:10.1029/2010JD014740, 2011.

Fall, S., Deffenbaugh, N. S., Niyogi, D., Pielke Sr., R. A., and Rochon, G.: Temperature and equivalent temperature over the United States (1979-2005), Int. J. Climatol., 30, 2045-2054, doi:10.1002/joc.2094, 2010.

Ferrari, R. L.: Folsom Lake: 2005 sedimentation survey, report, Bureau of Reclam., Tech. Serv. Cent., Denver, Colo., 2005.

Georgescu, M.: Evaluating the effect of land-use and land-cover change on climate in the greater Phoenix, AZ, region, Ph.D. dissertation, Department of Atmospheric Science, the State University of New Jersey, New Jersey, 185 pp., 2008.

Graf, W. L.: Dam nation: A geographic census of American dams and their large-scale hydrologic impacts, Water Resour. Res., 35, 1305-1311, doi:10.1029/1999WR900016, 1999.

Hanstrum, B. N., Mills, G. A., Watson,A., Monteverdi, J. P., and Doswell, C. A.: The Cool-Season Tornadoes of California and Southern Australia, Weather Forecast., 17, 705-722, doi:10.1175/1520-0434(2002)017<0705:TCSTOC>2.0.CO;2, 2002.

Harrington, J. Y.: The effects of radiative and microphysical processes on simulated warm and transition season Arctic stratus, Ph.D. dissertation, Colo. State Univ., Fort Collins, 289 pp., 1997.

Hossain, F., Degu, A. M., Yigzaw, W., Niyogi, D., Burian, S., Shepherd, J. M., and Pielke Sr., R. A.: Climate feedbackbased considerations to dam design, operations and water management in the 21st century, J. Hydrol. Eng., 17, 837-850, doi:10.1061/(ASCE)HE.1943-5584.0000541, 2012.
Jeton, A. E., Dettinger, M. E., and Smith, J. L.: Potential effects of climate change on streamflow, eastern and western slopes of the Sierra Nevada, California and Nevada. US Department of the Interior, US Geological Survey, 1996.

Kain, J. S. and Fritsch, M.: Convective parameterization for mesoscale models: The Kain-Fritsch scheme, The Representation of Cumulus Convection in Numerical Models, Meteorol. Mon. 24, American Meteorological Society, Boston, 165-170, 1993.

Kalnay, E.: The NCEP/NCAR 40-year reanalysis project, B. Am. Meteorol. Soc., 77, 437-471, doi:10.1175/15200477(1996)077<0437:TNYRP>2.0.CO;2, 1996.

Karl, T. R., Gleason, B. E., Menne, M. J., McMahon, J. R., Heim, J. R. R., Brewer, M. J., Kunkel, K. E., Arndt, D. S., Privette, J. L., Bates, J. J., Groisman, P. Y., and Easterling, D. R.: U.S. temperature and drought: Anomalies of spring and summer 2011-12 and trends, EOS Trans. AGU, 93, 473, 2012.

Kingsmill, D. E.,Neiman, P. J., Ralph, F. M., and White, A. B.: Synoptic and Topographic Variability of Northern California Precipitation Characteristics in Landfalling Winter Storms Observed during CALJET, Mon. Weather Rev., 134, 2072-2094, doi:10.1175/MWR3166.1, 2006.

Klemp, J. B. and Wilhelmson, R. B.: The simulation of threedimensional convective storm dynamics, J. Atmos. Sci., 35, 1070-1096, 1978.

Kuo, H. L.: Further studies of the parameterization of the influence of cumulus convection on large-scale flow, J. Atmos. Sci., 31, 1232-1240, doi:10.1175/15200469(1974)031<1232:FSOTPO>2.0.CO;2, 1974.

Mahmood R., Hubbard, K. G., Leeper, R. D., and Foster, S. A.: Increase in near-surface atmospheric moisture content due to land use changes: evidence from the observed dew point temperature data, Mon. Weather Rev., 136, 1554-1561, doi:10.1175/2007MWR2040.1, 2007.

Marshall Jr., C. H., Pielke Sr., R. A., Steyaert, L. T., and Willard, D. A.: The impact of anthropogenic land-cover change on the Florida peninsula sea breezes and warm season sensible weather, Mon. Weather. Rev., 132, 28-52, 2010.

Meyers, M. P., Walko, R. L., Harrington, J. Y., and Cotton, W. R.: New RAMS cloud microphysics parameterization, Part II: The two moment scheme, Atmos. Res., 45, 3-39, 1997.

Muchoney, D., Strahler, A., Hodges, J., and LoCastro, J.: The IGBP DISCover Confidence Sites and the System for Terrestrial Ecosystem Parameterization: Tools for Validating Global Land Cover Data, Photogramm. Eng. Remote Sens., 65, 1061-1067, 1999.

Narisma, G. T. and Pitman, A. J.: The impact of 200 years of land covers change on the Australian near-surface climate, J. Hydrometeorol., 4, 424-436, 2003.

Narisma, G. T., and Pitman, A. J.: Exploring the sensitivity of the Australian climate to regional land-cover-change scenarios under increasing $\mathrm{CO}_{2}$ concentrations and warmer temperature, Earth Interact., 10, 1-27, doi:10.1175/EI154.1, 2006. 
Pasqui, M., Gozzini, B., Grifoni, D., Meneguzzo, F., Messeri, G., Pieri, M., Rossi, M., and Zipoli, G.: Performances of the operational RAMS in a Mediterranean region as regard to quantitative precipitation forecasts, Sensitivity of precipitation and wind forecasts to the representation of land cover, applied meteorology foundation, FMA, available at: http://www.atmet.com/html/ workshop/workshop-4.shtml\#43 (last access: 2 August 2013), 2000.

Pielke Sr., R. A.: A comprehensive meteorological modeling system - RAMS, Meteorol. Atmos. Phys., 49, 69-91, doi:10.1007/BF01025401, 1992.

Pielke Sr., R. A.: Influence of the spatial distribution of vegetation and soils on the prediction of cumulus convective rainfall, Rev. Geophys., 39, 151-177, 2001.

Pielke Sr., R. A., Walko, R. L., Steyaert, L. T., Vidale, P. L., Liston, G. E., Lyons, W. A., and Chase, T. N.: The influence of anthropogenic landscape changes on weather in south Florida, Mon. Weather Rev., 127, 1663-1673, doi:10.1175/15200493(1999)127<1663:TIOALC>2.0.CO;2, 1999.

Pitman, A. J.: The evolution of, and revolution in, land surface schemes designed for climate models, Int. J. Climatol., 23, 479$510,2003$.

Schar, C., Luthi, D., Beyerle, U., and Heise, E.: The soil feedback: A process study with a regional climate model, J. Climatol., 12, 722-742, 1998.

Schneider, N., Eugster, W., and Schichler, B.: The impact of historical land-use changes on the near-surface atmospheric conditions on the Swiss Plateau, Earth Interact., 8, 1-27, doi:10.1175/10873562(2004)008<0001:TIOHLC>2.0.CO;2, 2004.

Shepherd, J. M.: A review of current investigations of urbaninduced rainfall and recommendations for the future, Earth Interact., 9, 1-27, doi:10.1175/EI156.1, 2005.

Sleeter, B. M.: Late 20th century land change in the Central California Valley Ecoregion, California Geogr., 48, 27-60, 2008.

Stohlgren, T. J., Thomas, N. C., Pielke Sr., R. A., Kittles, T. G. F., and Baron, J. S.: Evidence that local land use practices influence regional climate, vegetation, and stream flow patterns in adjacent natural areas, Global Change Biol., 4, 495-504, doi:10.1046/j.1365-2486.1998.t01-1-00182.x, 1998.

Sud, Y. C. and Smith, W. E.: The influence of surface roughness of deserts on the July circulation - A numerical study, Bound.-Lay. Meteorol., 33, 15-49, 1985. ter Maat, H. W., Moors, E. J., Hutjes, R. W. A., Holtslag, A. A. M., and Dolman, A. J.: Exploring the Impact of Land Cover and Topography on Rainfall Maxima in the Netherlands, J. Hydrometeorol., 14, 524-542, doi:10.1175/JHM-D-12-036.1, 2013.

Tremback, C. J., Tripoli, G. J., and Cotton, W. R.: A regional scale atmospheric numerical model including explicit moist physics and a hydrostatic time-split scheme, paper presented at 7th Conference on Numerical Weather prediction, 17-20 June 1985, Am. Meteorol. Soc., Montreal, Que., Canada, 433-434, 1985.

USACE - US Army Corps of Engineers: Stochastic modeling of extreme floods on the American River at Folsom dam - Flood frequency curve extension, Hydrol. Eng. Cent., Sacramento, Calif., 2005.

USBR - US Bureau of Reclamation: The story of Owyhee Project, available at: http://www.usbr.gov/pn (last access: 19 May 2011), 2009.

Vaccaro, J. J.: Interdecadal changes in the hydrometeorological regime of the Pacific Northwest and in the regional-tohemispheric climate regimes, and their linkages, US Geological Survey, water resources investigation report, also available at: http://pubs.usgs.gov/wri/wri024176/pdf/wri024176.pdf (last access: 21 June 2011), 2002.

Walko, R. L. and Tremback, C. J.: RAMS: Regional Atmospheric Modeling System, version 4.3/4.4 - Introduction to RAMS 4.3/4.4. ASTER Div., Mission Res., Inc., Fort Collins, Colo., 2002.

Woldemichael, A. T., Hossain, F., Pielke Sr., R. A., and Beltrán A.: Understanding the impact of dam-triggered land use/land cover change on the modification of extreme precipitation, Water Resour. Res., 48, W09547, doi:10.1029/2011WR011684, 2012.

Woldemichael, A. T., Hossain, F., and Pielke Sr., R. A.: Impacts of post-dam land-use/land-cover changes on modification of extreme precipitation in contrasting hydro-climate and terrain features, J. Hydrometeorol., 15, 777-800, doi:10.1175/JHM-D-13085.1, 2013.

Zhang, Y., Wallace, J. M., and Iwasaka, N.: Is climate variability over the North Pacific a linear response to ENSO?, J. Climate, 9, 1468-1478, 1996.

Zhao, M. and Pitman, A. J.: The impact of land cover change and increasing carbon dioxide on the extreme and frequency of maximum temperature and convective precipitation, Geophys. Res. Lett., 29, 1078, doi:10.1029/2001GL013476, 2002. 